Research article

\title{
Study of factors involved in the gravimetric separation process to treat soil contaminated by municipal solid waste
}

\author{
Ikbel Mouedhen, Lucie Coudert, Jean-François Blais*, Guy Mercier \\ Institut National de la Recherche Scientifique (Centre Eau Terre Environnement), Université du Québec, 490 rue de la Couronne, Québec, QC G1K 9A9, Canada
}

\section{A R T I C L E INFO}

\section{Article history:}

Received 18 May 2017

Received in revised form 29 November 2017

Accepted 8 December 2017

Available online $\mathrm{xxx}$

\section{Keywords:}

Inorganic contaminants

Soil remediation

Gravimetric process

Shaking table

Dense media separation

Box-Behnken design

\begin{abstract}
A B S T R A C T
The current research investigated the effectiveness of a gravimetric process (shaking table) to treat soil contaminated by municipal solid waste. A detailed characterization of the inorganic pollutants was performed, followed by concentrating the metals within smaller volumes using the shaking table technology. The densimetric examination of the 1-2 mm and $0.250-1 \mathrm{~mm}$ fractions of the contaminated soil showed that lead $(\mathrm{Pb})$, copper $(\mathrm{Cu})$, and tin $(\mathrm{Sn})$ were mostly concentrated in the heavy fraction (metal removals $>50 \%$ ). Scanning electron microscopy coupled with elemental analysis indicated the relevance of using gravimetric processes to treat this soil sample. The influence of shaking table parameters was determined using a Box-Behnken design. The tilt and washing water flow demonstrated significant effects on the motion of the 1-2 mm soil fraction and on the removal of $\mathrm{Pb}, \mathrm{Cu}$, and $\mathrm{Sn}$. The results obtained under the optimal settings of the shaking table defined using the Box-Behnken methodology when treating the 1-2 mm fraction were close to those obtained when using dense media separation. The recovered mass of the concentrate was approximately $20.8 \%\left(\mathrm{w} . \mathrm{w}^{-1}\right)$ of the total mass. The removals of $\mathrm{Pb}, \mathrm{Cu}$, and $\mathrm{Sn}$ were estimated to be $67.3 \%, 54.5 \%$ and $54.6 \%$ respectively. The predicted and experimental mass distributions of the medium (1-2 mm) and fine-sized $(0.250-1 \mathrm{~mm})$ particles were compared successively under some selected conditions. The mass distribution of both fractions showed similar tendencies in response to the forces applied by each condition. However, lowering the forces induced by the bumping action and the flowing film was recommended so as to efficiently treat the fine fraction $(0.250-1 \mathrm{~mm})$. The recovered mass of the concentrate $(10 \%)$ was slightly lower than that obtained by dense media separation (13\%). However, satisfactory removal yields were obtained for $\mathrm{Pb}, \mathrm{Cu}, \mathrm{and} \mathrm{Sn}$ $(42.7 \%, 23.6 \%$, and $35 \%$ respectively).
\end{abstract}

(C) 2017

\section{Introduction}

Industrial expansion and population growth densities led to the establishment of municipal solid waste management strategies (Collett et al., 1998). Waste combustion is commonly used to reduce the total volume of solid waste that should be disposed of by $80-90 \%$ (Prasad and Shih, 2016). The first such device was developed in England in 1870. Thereafter, incinerators began to appear in many industrialized countries to treat domestic, commercial, and industrial solid wastes (Chandler et al., 1997). Prior to the Second World War, the absence of serious environmental regulations promoted the discharge of toxic chemicals and ashes into the environment (Santoleri et al., 2000). Therefore, the inadequate management of waste has contributed to the contamination of urban soils (Hutton et al., 1988; Thornton, 2009). The contamination of soil by metals presents a potential risk for the exposed population and fauna (Olawoyin et al., 2012). The management of contaminated sites has become of a major concern in

\footnotetext{
* Corresponding author.

Email addresses: ikbel.mouedhen@ete.inrs.ca (I. Mouedhen); lucie.coudert@ete. inrs.ca (L. Coudert); blaisjf@ete.inrs.ca (J-F Blais); guy.mercier@ete.inrs.ca (G. Mercier)
}

developed countries. Remediation technologies available to treat sites contaminated by inorganic compounds are classified into physical, chemical and biological techniques. Rehabilitation costs involved are usually the major challenge defining the practical application of such remediation technologies (Khalid et al., 2017). Solidification/Stabilization is the most relevant technology and the most commonly used method to manage soil contaminated by inorganic compounds (Iskandar, 2000). It aims to reduce the mobility of the hazardous materials. In a second step, the contaminated soil is mixed with ordinary Portland cement to ensure a subsequent safe landfilling (Ucaroglu and Talinli, 2012). The costs related to the management range from \$US190-248 $\mathrm{m}^{-3}$ of treated soil (FRTR, 2016). Solidification/stabilization technique requires the maintenance of the secured systems and is deemed to be an unsustainable treatment technology (Guemiza et al., 2017). Hence, alternative and environmentally friendly solutions are necessary to treat soil contaminated by metals. For instance, bioremediation is a simple and economical treatment solution which involves plants, microorganisms and organic amendments to detoxify/remove the inorganic compounds from soils. The effectiveness of the biological techniques depends generally on the bioavailability of metals in the soil and concerns low to moderate polluted mediums (Khalid et al., 2017; Park et al., 2011). In the other hand, soil washing 
uses physical and chemical approaches to extract effectively metals from soil (Benschoten et al., 1997). Chemical agents such as chelating agents, acids and salt chloride solution are used to transfer the metals from the soils into an aqueous solution (Guo et al., 2016; Yao et al., 2012). Mineral processing technologies, such as gravimetric separation, are frequently implemented to reduce the use of chemicals. Moreover, the volume of soil to be safely managed is considerably reduced, which decreases the operating costs of the decontamination process (ranging from \$US70-187 $\mathrm{m}^{-3}$ of soil) (Dermont et al., 2008). Gravimetric processes are based on the motion of the soil particles in response to gravity and other forces, such as the resistance to the motion offered by the fluid. Specific gravity, weight, particle size, and shape are the key factors determining the effectiveness of the separation of contaminated particles from uncontaminated soil (Burt, 1999). A significant difference in the density between the soil particles and the particles bearing the inorganic contaminants is necessary to produce a satisfactory decontamination performance (Gosselin et al., 1999). Several works highlighted the suitability of gravimetric processes to efficiently decontaminate soils polluted by incinerator residues (Jobin et al., 2016a; Mercier et al., 2001). These studies reported high levels of $\mathrm{Pb}$ and $\mathrm{Cu}$ liberation degree according to a pollutant characterization of the municipal solid waste. According to these authors, iron oxides were widely or occasionally involved in the carrying phase of $\mathrm{Sn}, \mathrm{Cu}$, and $\mathrm{Pb}$, indicating that gravimetric processes would be a very promising treatment option (Jobin et al., 2016b; Mercier et al., 2001). Unit operations such as soil sizing and attrition scrubbing are usually involved prior to gravimetric treatment. Indeed, the application of a shaking table to treat contaminated soil is restricted to medium and coarse fractions $(0.063-2 \mathrm{~mm})$. Finer and coarser particles undergo further treatment such as chemical extraction or other physical treatments (flotation, jig, and magnetic separators, among others) (Dermont et al., 2008). Among the gravimetric processes, the most common equipment available to isolate these contaminated particles from uncontaminated soil are jigs, spirals, heavy-medium techniques, and shaking tables (USEPA, 1995). If used correctly, shaking tables demonstrate high selectivity and satisfactory metal recovery efficiencies, allowing the treatment of contaminated soil and mining ore. Particles introduced to the table are displaced by the forces of the washing water and the longitudinal stroke of the deck. Depending on the density of the particles, the stratification mechanism near the riffles of the deck is also involved in the concentration process. Hence, operational and design variables (characteristics of the deck) affect the treatment performance. Frequent operator attention and adjustment of the shaking table parameters are therefore needed to optimize the separation performance of contaminated particles from the uncontaminated fraction (Falconer, 2003). The principal operational parameters are the throughput of the solid, length and frequency of strokes, tilt of the deck, and water flow (Fitzpatrick et al., 2016). The shaking table has been used to treat a large range of soils, including those polluted by weapon ammunition, mining residues, slags or foundry residues, and municipal solid waste. The chemical and mineralogical heterogeneities of soils induce large variability in the observed performance. For instance, in the case of soils moderately contaminated by mining residues, the removal of $\mathrm{Zn}, \mathrm{Pb}$, and $\mathrm{Cu}$ ranged from $19 \%$ to $26 \%$. The required adjustments to enhance the decontamination of these soils were defined as follows: $20^{\circ}$ tilt, feed water flow of $3.5 \mathrm{~L} \mathrm{~min}^{-1}$, washing water flow of $8 \mathrm{~L} \mathrm{~min}^{-1}$, and feed pulp composition of $20 \%$ total solids $\left(\mathrm{w} \cdot \mathrm{w}^{-1}\right)$ (Veetil et al., 2014). For a soil highly contaminated by $\mathrm{Pb}$, $\mathrm{Zn}, \mathrm{Cu}$, and $\mathrm{Sb}$ found in military shooting grounds, the removals ranged from $60 \%$ to $96 \%$ under a feed water flow of $3.5 \mathrm{~L} \mathrm{~min}^{-1}$, a washing water flow of $8 \mathrm{~L} \mathrm{~min}^{-1}$, and a pulp comprising $70 \%$ total solids $\left(\mathrm{w} \cdot \mathrm{w}^{-1}\right)$ (Laporte-Saumure et al., 2010). The research of Bisone et al. (2013) focused on the treatment of the $0.125-1 \mathrm{~mm}$ fraction of a soil contaminated by slags and foundry residues. These samples contained high levels of $\mathrm{Cu}$ and $\mathrm{Zn}$. The tilt was adjusted to the maximum level. The principal and secondary water flows were fixed at $6 \mathrm{~L} \mathrm{~min}^{-1}$, and $3.5 \mathrm{~L} \mathrm{~min}^{-1}$, successively. The stroke frequency was adjusted to 360 Strokes $\mathrm{min}^{-1}$. The shaking table treatment allowed the removal of $44-68 \%$ of $\mathrm{Cu}$. The removal of $\mathrm{Zn}$ varied from 30 to $44 \%$. In the case of a soil highly contaminated by municipal solid waste, the removals of $\mathrm{Pb}, \mathrm{Zn}, \mathrm{Cu}, \mathrm{Sn}$, and As ranged from $49 \%$ to $80 \%$ under an $11^{\circ}$ tilt, a stroke frequency of 500 strokes $\cdot \mathrm{min}^{-1}$, a feed water flow of $5 \mathrm{~L} \mathrm{~min}^{-1}$, a washing water flow of $5 \mathrm{~L} \mathrm{~min}^{-1}$, and a solid throughput of $100 \mathrm{~g} \mathrm{~min}^{-1}$ (Jobin et al., 2015). Another study, which investigated the decontamination of soil polluted by municipal solid waste, reported that the removal yields of $\mathrm{Pb}, \mathrm{Zn}, \mathrm{Cu}$, and $\mathrm{Sn}$ varied from 0 to $61.2 \%$. The soil was dry fed and the optimal settings comprised a slope ratio ranging from 1:55-1:96, a stroke frequency of 500 strokes $\cdot \mathrm{min}^{-1}$, and a pulp composition of $10 \%$ total solids $\left(\mathrm{w}^{\cdot} \cdot \mathrm{w}^{-1}\right)$ (Mercier, 2000; Mercier et al., 2001). Consequently, optimal settings vary according to the nature and/or the level of contamination. Modeling the mechanism of the shaking table can help to improve our understanding of the concentration process occurring during the treatment. Previous work investigated the possibility of modeling the performance of the shaking table to recover cassiterite from ore using the Box-Behnken response surface methodology. The statistical design was helpful for finding the optimal parameters of Sn recovery (Youssef et al., 2009).

Hence, a Box-Behnken design was used in the present study to evaluate the influence of operational parameters on the performance of the shaking table, which removed metals from soil contaminated by municipal solid waste. Moreover, the specific characteristics of the contamination and the operational settings involved in the separation process were investigated.

\section{Material and methods}

\subsection{Feedstock treatment}

Experiments were carried out with soil samples contaminated by municipal solid waste. More specifically, soil samples were collected from inorganic contaminated land, located in the site of Pointe au Lièvre in Quebec City (Canada). According to the history of the site, the contamination is old and mainly caused by the successive operation of two incinerators from 1939 until 1970. Samples were wet-sieved to produce several fractions, using a vibrating screen $\left(\right.$ Sweco $\left.^{\mathrm{TM}}\right)$ and different sieves. Fractions ranging from 1 to $2 \mathrm{~mm}$ and $0.250-1 \mathrm{~mm}$ were generated. Then, these soil fractions were put through a scrubbing attrition step performed at $1500 \mathrm{rpm}$ for a duration of $10 \mathrm{~min}$ with a solid-liquid ratio fixed at $30 \%\left(\mathrm{w} \cdot \mathrm{w}^{-1}\right)$. Attrition disintegrates agglomerates and liberates particles from slim coatings, enhancing the performance of a gravimetric process train (Marino et al., 1997).

\subsection{Dense media separation}

Tetrabromoethane (TBE $-\mathrm{C}_{2} \mathrm{H}_{2} \mathrm{Br}_{4}$ ) was used to characterize the density distribution of each soil fraction used in this study. The liquid density was adjusted to $1.5 \mathrm{~g} \mathrm{~cm}^{-3}$ using ethanol $\left(\mathrm{EtOH}-\mathrm{C}_{2} \mathrm{H}_{6} \mathrm{O}\right)$. Dense media separation was performed on $100 \mathrm{~g}$ of each soil sample collected from the entire soil fraction using Riffle-type Sample Splitters. Experiments were performed in triplicate. For the 1-2 mm soil fraction, the densities of the different products obtained were lower 
than $1.5 \mathrm{~g} \mathrm{~cm}^{-3}$, between 1.5 and $2.9 \mathrm{~g} \mathrm{~cm}^{-3}$, and higher than $2.9 \mathrm{~g} \mathrm{~cm}^{-3}$ (pure TBE). The lightest fraction $\left(<1.5 \mathrm{~g} \mathrm{~cm}^{-3}\right)$ corresponds to the organic matter whereas the heaviest fraction $\left(>2.9 \mathrm{~g} \mathrm{~cm}^{-3}\right)$ corresponds to the concentrate. For the $0.250-1 \mathrm{~mm}$ soil fraction, the densities of the different products obtained were lower than $2.9 \mathrm{~g} \mathrm{~cm}^{-3}$ and higher than $2.9 \mathrm{~g} \mathrm{~cm}^{-3}$.

\subsection{Gravimetric separation}

\subsubsection{Experimental method}

A Laboratory Wilfley Table (Outokumpu Technology, model 13A-SA) with a rectangular shape ( $1.02 \mathrm{~m}$ length and $0.46 \mathrm{~m}$ width) was used to treat contaminated soil fractions (Fig. 1). For each experiment, the solid flow was adjusted. The dry feedstock was introduced using a vibratory feeder. Three exits were selected (Fig. 1):

- exit E1, which collected the light output mass;

- exits E4, E5, E6, and E7, which received the concentrate (metal enriched product); and

- exits E2 and E3, which received the treated soil.

All generated shaking table exits were weighed. Their densities were determined using a Pycnometer (AccuPyc 1330, Micromeritics).

\subsubsection{Preliminary assays}

The influence of six variables (tilt, feed water flow, washing water flow, stroke frequency, stroke length, and solid throughput) affecting the gravimetric separation process was studied on the 1-2 mm soil fraction. All the experiments were performed in triplicate. Preliminary tests conducted with a control soil showed that physical separation was not affected by solid throughput. The independence of stroke length and stroke frequency was verified to determine whether their influence can be studied using a response surface methodology. However, feed water flow and washing water flow are dependent factors.

\subsubsection{Box-Behnken design}

A response surface methodology (Box-Behnken design) was used to evaluate the effect of some variables and their interactions on the performance of the shaking table with regard to contaminated particle separation from uncontaminated soil. The Box-Behnken design is a statistical method that can be used to optimize operating parameters using the minimum number of experiments. According to the Box-Behnken design, the response can be estimated using second-order prediction models (Equation (1)) (Govarthanan et al., 2014; Mocellin et al., 2015).

$$
Y=\beta_{0}+\sum_{j=1}^{K} \beta_{j} x_{j}+\sum_{j=1}^{k} \beta_{j j} x_{j}^{2}+\sum_{i} \sum_{<j=2}^{k} \beta_{i j} x_{i} x_{j}+e_{i}
$$

where $Y$ is the response; $\beta j, \beta j j$, and $\beta i j$ are the coefficients of the main effects, the quadratic effects, and the interaction between the main effects; and $e_{i}$ is the random error.

For this series of experiments, the solid flow was set at $100 \mathrm{~g} \mathrm{~min}^{-1}$ and the feed water flow was fixed at $2 \mathrm{~L} \mathrm{~min}^{-1}$. Four relevant factors (tilt, washing water flow, stroke length, and stroke frequency) were considered in this study. Their effects on the mass and density of the concentrate, as well as metal removal yields, were studied. The real and coded levels of each variable are presented in Table 1 . The values of coded variables vary over the same range (from -1 to +1 ), allowing the comparison of the effects of each variable. They were calculated using Equation (2).

$$
x_{i}=\frac{\left(x_{i}-x_{0}\right)}{\Delta x}
$$

where $x_{i}$ is the coded value, $x_{o}$ is the value of the variable at the center point, and $\Delta x$ is the step change.

A total of 29 tests were conducted using Equation (3) (Ferreira et al., 2007).

$$
N=n *\left(2 * k *(k-1)+C_{0}\right)
$$

where $k$ and $C_{0}$ correspond to the number of numeric factors and



Fig. 1. Schematic illustration of the shaking table. 
Table 1

Range of selected factors.

\begin{tabular}{lllll}
\hline Parameters & Unit & Range & \\
\hline & & -1 & 0 & 1 \\
\hline Tilt & $\circ$ & 8 & 11 & 14 \\
Washing water flow & $\mathrm{L} \cdot \mathrm{min}^{-1}$ & 4 & 6 & 8 \\
Stroke length & $\mathrm{mm}$ & 11.0 & 12.5 & 14.0 \\
Stroke frequency & $\mathrm{rpm}$ & 300 & 400 & 500 \\
\hline
\end{tabular}

the center point respectively ( $k=4$ and $C_{0}=5$ in the present study), and $n$ is the number of categorical factors.

Following the experiments and the statistical analysis, a validation test under the optimal predicted conditions was performed in triplicate.

Secondly, the effect of the shaking table parameters on the motion of medium-sized particles (1-2 mm) was exploited to treat the finer fraction $(0.250-1 \mathrm{~mm})$ of the contaminated soil.

\subsection{Analytical methods}

The concentrations of $\mathrm{Al}, \mathrm{Fe}, \mathrm{Cu}, \mathrm{Pb}, \mathrm{Sn}$ and $\mathrm{Zn}$ were followed during all assays of attrition, dense media separation and shaking table separation. Regarding the limits values for various contaminants fixed by the Land Protection and Rehabilitation Regulation in the Province of Quebec (Canada), $\mathrm{Cu}, \mathrm{Pb}, \mathrm{Sn}$ and $\mathrm{Zn}$ were considered as the most problematic inorganic compounds. Each soil sample was finely ground and digested using the aqua regia method (MA. 100 - Lix.com.1.1) (CEAEQ, 2010). Certified soil samples (SC0063618, LKSD-2 and LKSD-4) were used to ensure the quality of the digestion method. Metal concentrations in liquid samples obtained from the digestion method were determined using ICP-AES. Certified solutions (multi-element standard 900-Q30-002, SCP Science) were used to ensure the conformity of the measures.

\subsection{Calculations}

Dense media ensures a high efficiency of separation. It offers an ideal separation of contaminants from uncontaminated particles (Wills, 2011). Accordingly, practical comparison between the performance of dense media separation and the treatment of contaminated soil fractions using the shaking table was considered. Hence, the mass removal efficiency and metal removal efficiency ratios (RE and $\mathrm{R}_{\mathrm{M}}(\mathrm{M})$ ) were calculated during the treatment of the 1-2 mm soil fraction according to Equations (4) and (5).

\section{$R E$}

Total mass proportion of concentrate removed by the $s$. $=\frac{\text { Total mass proportion of concentrate removed by dense } \mathrm{m}}{\mathrm{T}}$

Total mass proportion of concentrate removed by the shakin:

$$
\left.-\frac{\text { Mass collected at E2 and E3 }(\mathrm{g})}{\text { Total mass }(\mathrm{g})}\right)
$$

$$
\begin{aligned}
& R_{M}(M) \\
& =\frac{\text { Metal removal by shaking table }(\%)}{\text { Metal removal by dense media separation(\%) }}
\end{aligned}
$$

$$
\begin{aligned}
& \text { Metal removal }(\%) \\
& =100 \\
& *\left(1-\frac{\text { Mass of metal obtained at E2 and E3 }(\mathrm{g})}{\text { Total mass of metal }(\mathrm{g})}\right)
\end{aligned}
$$

Theoretically, the RE ratio may vary from 0 to values higher than 1. When RE is lower than 1, this reflects that the mass separated and collected in exists E4, E5, E6 and E7 of the shaking table is lower than the mass separated by the dense media. These results indicate that a proportion of the contamination is concentrated in the exits E2 and E3 instead of the desired outputs (E4, E5, E6 and 7). Therefore, the forces involved in the separation process promote the motion of a proportion of the contaminated particles until the middling of the deck instead of the concentrate zone. In this case, the separation by shaking table is less efficient than that of dense media. When RE values are higher than 1 , this indicates that the mass removed by shaking table is higher than that removed by dense media. The forces on the deck promote the motion of both heavy and uncontaminated particles to the concentrate zone (E4, E5, E6 and E7). When the RE ratio is equal to 1, ideal settings of the gravimetric device are reached, regarding only the mass removal parameter. The performance of the shaking table is similar to that of dense media separation.

When $R E$ varies from 0 to 1 , the values of $R_{M}(M)$ may vary also from 0 to 1 . The threshold 1 reflects a maximum removal of the metal ' $M$ ' with the shaking table technology.

For the experiments performed on the $0.250-1 \mathrm{~mm}$ soil fraction, the total removed mass of the concentrate as well as the metal removal, were calculated according Equations (6) and (7).

Total mass proportion of concentrate removed by the shakin: $=100$

$*\left(1-\frac{\text { Mass collected at E1, E2 and E3 }(\mathrm{g})}{\text { Total mass }(g)}\right)$

$$
\begin{aligned}
& \text { Metal removal }(\%) \\
& =100 \\
& *(1 \\
& \left.\quad-\frac{\text { Mass of metal obtained at E1, E2 and E3 }(\mathrm{g})}{\text { Total mass of metal }(\mathrm{g})}\right)
\end{aligned}
$$

\section{Results and discussion}

\subsection{Characterization of soil fractions treated by attrition scrubbing}

The chemical analysis of the total content of inorganic compounds in the bulk soil revealed high concentrations of $\mathrm{Cu}\left(705 \mathrm{mg} \mathrm{kg}^{-1}\right), \mathrm{Pb}$ (1494 $\left.\mathrm{mg} \mathrm{kg}^{-1}\right)$, Sn $\left(484 \mathrm{mg} \mathrm{kg}^{-1}\right)$ and $\mathrm{Zn}\left(1339 \mathrm{mg} \mathrm{kg}^{-1}\right)$. As well, high levels of $\mathrm{Fe}\left(75,729 \mathrm{mg} \mathrm{kg}^{-1}\right)$ and $\mathrm{Al}\left(8470 \mathrm{mg} \mathrm{kg}^{-1}\right)$ were de- 
termined. These latter largely contributed to the composition of the carrying phases with which the heavy metal can be associated. The fine fraction $(<0.250 \mathrm{~mm})$ represented $19.8 \%\left(\mathrm{w} . \mathrm{w}^{-1}\right)$ of the total soil. The $0.250-2 \mathrm{~mm}$ and the fraction $>2 \mathrm{~mm}$ represented $23.1 \%$ and $57 \%\left(\mathrm{w} . \mathrm{w}^{-1}\right.$ ) of the total soil, respectively. All the fractions were highly contaminated by $\mathrm{Pb}, \mathrm{Cu}, \mathrm{Sn}$ and $\mathrm{Zn}$. Therefore, each soil fraction required a specific treatment in order to ensure a safe use of the soil. Since the shaking table concerns to treat particles sized from $0.100 \mathrm{~mm}$ to $3 \mathrm{~mm}$ (Wills, 2011), the current study focused on the $0.250-1 \mathrm{~mm}$ and $1-2 \mathrm{~mm}$ fractions of the soil. The shape of bottom and fly ash particles emerging from municipal solid waste incineration is usually irregular (Chang et al., 1999). Hence, attrition scrubbing is often necessary to enhance their sphericity and promote their separation from the uncontaminated soil, thereby removing some portion of the contaminants (Jobin et al., 2015). As mentioned previously, wet screening and attrition scrubbing were necessary to prepare the soil fractions for the gravimetric treatment and to allow for better treatment performance. Attrition scrubbing is a physical process that allows for the disaggregation of aggregates and the liberation of the thin film on the surface of particles (Marino et al., 1997; Stražišar and Sešelj, 1999). According to the study carried out by Jobin et al. (2015), approximately $10 \%$ of highly contaminated sludge was produced during the preconditioning step of the $1-2 \mathrm{~mm}$ and $0.250-1 \mathrm{~mm}$ soil fractions respectively. In the present study, the 1-2 $\mathrm{mm}$ soil fraction initially contained $727 \mathrm{mg} \mathrm{kg}^{-1}$ of $\mathrm{Cu}, 1640 \mathrm{mg} \mathrm{kg}^{-1}$ of $\mathrm{Pb}, 596 \mathrm{mg} \mathrm{kg}^{-1}$ of $\mathrm{Sn}$, and $1290 \mathrm{mg} \mathrm{kg}^{-1}$ of $\mathrm{Zn}$. The concentrations of $\mathrm{Cu}, \mathrm{Pb}, \mathrm{Sn}$, and $\mathrm{Zn}$ in the $0.250-1 \mathrm{~mm}$ fraction were $463 \mathrm{mg} \mathrm{kg}^{-1}, 1663 \mathrm{mg} \mathrm{kg}^{-1}$, $628 \mathrm{mg} \mathrm{kg}^{-1}$, and $1200 \mathrm{mg} \mathrm{kg}^{-1}$ respectively. The large presence of $\mathrm{Cu}, \mathrm{Pb}, \mathrm{Sn}$, and $\mathrm{Zn}$ in the soil is a result of combustion of batteries, printed circuit boards, drink and food containers, pigments in paint, plastics, glass, and pesticides (Chandler et al., 1997; Harrison and Hester, 1994; Wei et al., 2011). Following to the attrition scrubbing treatment, the measured concentrations of metals in the $1-2 \mathrm{~mm}$ fraction were $658 \mathrm{mg} \mathrm{kg}^{-1}$ of $\mathrm{Cu}, 1925 \mathrm{mg} \mathrm{kg}^{-1}$ of $\mathrm{Pb}, 551 \mathrm{mg} \mathrm{kg}^{-1}$ of $\mathrm{Sn}$, and $1020 \mathrm{mg} \mathrm{kg}^{-1}$ of $\mathrm{Zn}$. The concentrations of inorganic contaminants in the $0.250-1 \mathrm{~mm}$ soil fraction were slightly lower, with $343 \mathrm{mg} \mathrm{kg}^{-1}$ of $\mathrm{Cu}, 1040 \mathrm{mg} \mathrm{kg}^{-1}$ of $\mathrm{Pb}, 609 \mathrm{mg} \mathrm{kg}^{-1}$ of $\mathrm{Sn}$, and $955 \mathrm{mg} \mathrm{kg}^{-1}$ of $\mathrm{Zn}$. According to the mass balance of the $1-2 \mathrm{~mm}$ fraction, low to moderate removals of metals were obtained. They varied from 3.47 to $35.0 \%$ depending on the contaminant. The concentrations of $\mathrm{Cu}, \mathrm{Pb}$ and $\mathrm{Sn}$ were maintained closed to those determined before the treatment (error threshold of 5\%). Consequently, the attrition scrubbing had no significant effect on the removal of these contaminants. Only the concentration of $\mathrm{Zn}$ significantly decreased following this treatment. The generated sludge represented $17.8 \%$ of the total mass of the 1-2 mm soil fraction. In the other hand, the attrition scrubbing treatment allowed the removal of $16.3 \%\left(\mathrm{w} . \mathrm{w}^{-1}\right)$ of the total mass of the $0.250-1 \mathrm{~mm}$ fraction. The heavy metals removal varied from 18.8 to $47.6 \%$. A significant decrease of $\mathrm{Cu}, \mathrm{Pb}$ and $\mathrm{Zn}$ were achieved. However, the attrition scrubbing had no significant effect on the concentration of Sn (error threshold of 5\%). The concentrations were still higher than the mean natural background of $\mathrm{Cu}\left(38.9 \mathrm{mg} \mathrm{kg}^{-1}\right), \mathrm{Pb}$ $\left(17 \mathrm{mg} \mathrm{kg}^{-1}\right)$, Sn $\left(2.5 \mathrm{mg} \mathrm{kg}^{-1}\right)$, and $\mathrm{Zn}\left(70 \mathrm{mg} \mathrm{kg}^{-1}\right)$ determined for uncontaminated soils around the world (European countries, United States, Japan and Brazil) (Alloway, 2013; Burt et al., 2003; Erikssonv, 2001; FOREG, 2005; Kabata-Pendias, 2004, 2011; Kabata-Pendias and Dudka, 1991; Lado et al., 2008; Shacklette and Boerngen, 1984; Takeda et al., 2004).

Table 2 presents the elemental composition of pollutants according to the microscopic analysis performed on numerous particles of the concentrates obtained by dense media separation. The examined particles exhibited numerous phases with large mineralogical heterogeneity. For example, particles containing $\mathrm{Pb}$ were identified as oxides of $\mathrm{Pb}, M-\mathrm{Pb}$ oxides, $\mathrm{Pb}$ carbonates, and $\mathrm{Pb}$ silicates. This contaminant was highly liberated and associated to one or more carrying phases like $\mathrm{Fe}$ oxides, $\mathrm{Ba}$ sulfates, and $\mathrm{Ca}$ carbonates/oxides. According to these results, $\mathrm{Sn}$ was identified as $\mathrm{Sn}$ oxides, $M$-Sn oxides, and alloys of $\mathrm{Sn}$ and other metals. $\mathrm{Cu}$ was also found to exist as oxides, $M-\mathrm{Cu}$ oxides, and as a native element alloyed with other metals. All the $\mathrm{Pb}, \mathrm{Sn}$, and $\mathrm{Cu}$ were totally liberated or carried by one or a mix of phases. The microscopic analysis revealed the presence of $\mathrm{Zn}$ in heavy particles, in the form of $M-\mathrm{Zn}$ oxides and $\mathrm{Zn}$ silicates. $\mathrm{Zn}$ was generally associated with other phases such as Ti-Ba oxides or a combination of $\mathrm{Fe}$ and $\mathrm{Ca}$ carbonates. This wide mineralogical variation is primarily explained by the source of contamination. Indeed, municipal solid waste comprises the waste of households, public areas, shops, and markets, and can sometimes contain industrial non-hazardous waste too (Weidemann, 2014). The elemental composition of particles is also affected by the fate of metals during the incineration process and inside the soil after municipal solid waste incinerator residues are disposed of to the landfill. The following factors are able to affect the mineralogical properties: characteristics of the incineration system, redox atmosphere, temperature, $\mathrm{pH}$, and presence of alkalis and mineral substances. Volatilization and condensation phenomena are involved during the incineration process. Adsorption, precipitation, organometallic reaction, and incrustation in the crystalline lattices of minerals can occur when the ashes are in contact with the soil (Dong et al., 2015; Horowitz, 1991; Iskandar, 2000).

The nature of the carrying phase with which metals are embedded or adsorbed controls the fate of contaminants during the gravimetric treatment (Dermont et al., 2008). Therefore, Table 2 classifies the examined particles into three classes (totally liberated phase, associated to heavy phase, and associated to light phase). Fig. 2 presents an example of each defined class. Firstly, totally liberated particles have high densities and can be easily removed using gravimetric processes (Fig. 2-a). In the present study, some percent of the $\mathrm{Cu}$, $\mathrm{Pb}$, and $\mathrm{Sn}$ were totally liberated. The second class concerned particles that were associated with the heavy phase, such as iron oxides (Fig. 2-b). In the present study, this mainly involved $\mathrm{Pb}, \mathrm{Sn}$, and $\mathrm{Cu}$. High concentrations of Fe were noted, varying from $64,270 \mathrm{mg} \mathrm{kg}^{-1}$ to $103,100 \mathrm{mg} \mathrm{kg}^{-1}$ for the $0.250-1 \mathrm{~mm}$ and $1-2 \mathrm{~mm}$ soil fractions respectively. As for the first class, the particles associated with the heavy phase can be easily removed by gravimetric treatments. The third class concerned particles that were associated with a light phase or a mix of light and heavy phases (Fig. 2-c). The density of this class can be affected by the volume of the light phase, which can reduce the effectiveness of the gravimetric processes. . Prior studies classified the numerous carrying phases into the melt glass phase, silicate mineral phase (especially melilite: $\left.[\mathrm{CaNa}]_{2}\left[\mathrm{AlMgFe}^{2+}\right][\mathrm{AlSi}] \mathrm{SiO}_{7}\right]$, and pseudowollastonite: $\mathrm{CaSiO}_{3}$ ), and calcium-rich mineral phases (Lime: $\mathrm{CaO}$, Portlandite: $\mathrm{Ca}(\mathrm{OH})_{2}$, and Calcite: $\left.\mathrm{CaCO}_{3}\right)$. They are characterized by low densities, which vary from $2.3 \mathrm{~g} \cdot \mathrm{cm}^{-3}-2.9 \mathrm{~g} \mathrm{~cm}^{-3}$. The presence of heavy phases, such as metal alloys and magnetic spinels (e.g., magnetite), was also reported (Chandler et al., 1997; Wei et al., 2011).

\subsection{Contaminant removal performance of dense media separation from treated soil fractions by attrition scrubbing}

The mass proportions and concentrations of the different inorganic contaminants present at each dense media separation exit are presented in Table 3. According to these results, $17.5 \%$ and $13.1 \%$ of 
Table 2

Mineralogical characterization of selected particles of contaminated soils by municipal solid waste.

\begin{tabular}{|c|c|c|c|c|c|}
\hline Number of the particle examined & \multicolumn{3}{|c|}{ Phase containing the contaminant } & Carrying phase of the contaminant & $>$ \\
\hline 1 & $\mathrm{~Pb}_{\mathrm{a}} \mathrm{O}_{\mathrm{b}}$ & & & & \\
\hline 2 & $\mathrm{~Pb}_{\mathrm{a}} \mathrm{C}_{\mathrm{b}} \mathrm{O}_{\mathrm{c}}$ & & & - & \\
\hline 3 & $\mathrm{Sn}_{\mathrm{a}} \mathrm{Pb}_{\mathrm{b}} \mathrm{O}_{\mathrm{c}}$ & & & - & \\
\hline 4 & $\mathrm{~Pb}_{\mathrm{a}} \mathrm{Al}_{\mathrm{b}} \mathrm{O}_{\mathrm{c}} \mathrm{C}_{\mathrm{d}}$ & & & - & $>$ \\
\hline 5 & $\mathrm{~Pb}_{\mathrm{a}} \mathrm{Fe}_{\mathrm{b}} \mathrm{Si}_{\mathrm{c}} \mathrm{O}_{\mathrm{d}}$ & & & - & \\
\hline 6 & $\mathrm{Cu}_{\mathrm{a}} \mathrm{Pb}_{\mathrm{b}} \mathrm{Sn}_{\mathrm{c}} \mathrm{O}_{\mathrm{d}}$ & & & - & \\
\hline 7 & 1: $\mathrm{Pb}_{\mathrm{a}} \mathrm{O}_{\mathrm{b}}$ & 2: $\mathrm{Pb}_{\mathrm{a}} \mathrm{Ca}_{\mathrm{b}} \mathrm{O}_{\mathrm{c}}$ & & - & \\
\hline 8 & 1: $\mathrm{Pb}_{\mathrm{a}} \mathrm{O}_{\mathrm{b}}$ & 2: $\mathrm{Sn}_{\mathrm{a}} \mathrm{Pb}_{\mathrm{b}} \mathrm{O}_{\mathrm{c}}$ & & - & \\
\hline 9 & 1: $\mathrm{PbaBa}_{\mathrm{b}} \mathrm{S}_{\mathrm{c}} \mathrm{O}_{\mathrm{d}}$ & 2: $\mathrm{Pb}_{\mathrm{a}} \mathrm{Ba}_{\mathrm{b}} \mathrm{Fe}_{\mathrm{c}} \mathrm{O}_{\mathrm{d}}$ & & - & \\
\hline 10 & 1: $\mathrm{Pb}_{\mathrm{a}} \mathrm{O}_{\mathrm{b}}$ & 2: $\mathrm{Pb}_{\mathrm{a}} \mathrm{Ba}_{\mathrm{b}} \mathrm{Fe}_{\mathrm{c}} \mathrm{O}_{\mathrm{d}}$ & 3: $\mathrm{Pb}_{\mathrm{a}} \mathrm{Br}_{\mathrm{b}} \mathrm{Fe}_{\mathrm{c}} \mathrm{O}_{\mathrm{d}}$ & - & \\
\hline 11 & 1: $\mathrm{Pb}_{\mathrm{a}} \mathrm{C}_{\mathrm{b}} \mathrm{O}_{\mathrm{c}}$ & 2: $\mathrm{Pb}_{\mathrm{a}} \mathrm{Sn}_{\mathrm{b}} \mathrm{O}_{\mathrm{c}} \mathrm{C}_{\mathrm{d}}$ & 3: $\mathrm{Sn}_{\mathrm{a}} \mathrm{C}_{\mathrm{b}} \mathrm{O}_{\mathrm{c}}$ & - & \\
\hline 12 & 1: $\mathrm{PbaSn}_{\mathrm{b}} \mathrm{O}_{\mathrm{c}} \mathrm{C}_{\mathrm{d}}$ & 2: $\mathrm{Sn}_{\mathrm{a}} \mathrm{O}_{\mathrm{b}}$ & 3: $\mathrm{Pb}_{\mathrm{a}} \mathrm{Sn}_{\mathrm{b}} \mathrm{C}_{\mathrm{c}} \mathrm{O}_{\mathrm{d}}$ & - & \\
\hline 13 & 1: $\mathrm{Sn}_{\mathrm{a}} \mathrm{O}_{\mathrm{b}}$ & 2: $\mathrm{Sn}_{\mathrm{a}} \mathrm{Fe}_{\mathrm{b}} \mathrm{O}_{\mathrm{c}}$ & & - & \\
\hline 14 & 1: $\mathrm{Cu}_{\mathrm{a}} \mathrm{O}_{\mathrm{b}}$ & 2: $\mathrm{Cu}_{\mathrm{a}} \mathrm{Fe}_{\mathrm{b}} \mathrm{O}_{\mathrm{c}}$ & & - & \\
\hline 15 & $\mathrm{~Pb}_{\mathrm{a}} \mathrm{Fe}_{\mathrm{b}} \mathrm{O}_{\mathrm{c}}$ & & & $\mathrm{Fe}_{\mathrm{a}} \mathrm{O}_{\mathrm{b}}$ & \\
\hline 16 & $\mathrm{~Pb}_{\mathrm{a}} \mathrm{C}_{\mathrm{b}} \mathrm{O}_{\mathrm{c}}$ & & & $\mathrm{B}_{\mathrm{a}} \mathrm{Ba}_{\mathrm{b}} \mathrm{S}_{\mathrm{c}} \mathrm{C}_{\mathrm{d}} \mathrm{O}_{\mathrm{e}}$ & \\
\hline 17 & $\mathrm{Sn}_{\mathrm{a}} \mathrm{O}_{\mathrm{b}}$ & & & $\mathrm{Fe}_{\mathrm{a}} \mathrm{C}_{\mathrm{b}} \mathrm{O}_{\mathrm{c}}$ & \\
\hline 18 & $\mathrm{Sn}-\mathrm{Fe}$ & & & $\mathrm{Fe}_{\mathrm{a}} \mathrm{O}_{\mathrm{b}}$ & \\
\hline 19 & $\mathrm{Ti}_{\mathrm{a}} \mathrm{Zn}_{\mathrm{b}} \mathrm{O}_{\mathrm{c}}$ & & & 1: $\mathrm{Ba}_{\mathrm{a}} \mathrm{Cr}_{\mathrm{b}} \mathrm{O}_{\mathrm{c}}$ & \\
\hline 20 & 1: $\mathrm{Sn}_{\mathrm{a}} \mathrm{Fe}_{\mathrm{b}} \mathrm{O}_{\mathrm{c}}$ & 2: $\mathrm{Sn}-\mathrm{Cu}-\mathrm{Fe}$ & & $\mathrm{Fe}_{\mathrm{a}} \mathrm{O}_{\mathrm{b}}$ & \\
\hline 21 & 1: $\mathrm{Sn}-\mathrm{Fe}$ & 2: $\mathrm{Sn}_{\mathrm{a}} \mathrm{Fe}_{\mathrm{b}} \mathrm{O}_{\mathrm{c}}$ & & $\mathrm{Fe}_{\mathrm{a}} \mathrm{O}_{\mathrm{b}}$ & \\
\hline 22 & 1: $\mathrm{Sn}_{\mathrm{a}} \mathrm{Br}_{\mathrm{b}} \mathrm{FecO}_{\mathrm{d}}$ & 2: $\mathrm{Sn}_{\mathrm{a}} \mathrm{Fe}_{\mathrm{b}} \mathrm{O}_{\mathrm{c}}$ & & $\mathrm{Fe}_{\mathrm{a}} \mathrm{O}_{\mathrm{b}}$ & \\
\hline 23 & 1: $\mathrm{Sn}_{\mathrm{a}} \mathrm{Cu}_{\mathrm{b}} \mathrm{Ni}_{\mathrm{c}} \mathrm{Fe}_{\mathrm{d}} \mathrm{O}_{\mathrm{e}}$ & 2: $\mathrm{Sn}_{\mathrm{a}} \mathrm{Fe}_{\mathrm{b}} \mathrm{O}_{\mathrm{c}}$ & & $\mathrm{Fe}_{\mathrm{a}} \mathrm{O}_{\mathrm{b}}$ & \\
\hline 24 & 1: Sn-Fe & 2: $\mathrm{SnFeO}_{\mathrm{C}}$ & & $\mathrm{Fe}_{\mathrm{a}} \mathrm{C}_{\mathrm{b}} \mathrm{O}_{\mathrm{c}}$ & \\
\hline 25 & 1: $\mathrm{Sn}_{\mathrm{a}} \mathrm{Fe}_{\mathrm{b}} \mathrm{O}_{\mathrm{c}}$ & 2: Sn-Fe & & $\mathrm{Fe}_{\mathrm{a}} \mathrm{O}_{\mathrm{b}}$ & \\
\hline 26 & 1: $\mathrm{Sn}_{\mathrm{a}} \mathrm{O}_{\mathrm{b}}$ & 2: $\mathrm{Sn}_{\mathrm{a}} \mathrm{Fe}_{\mathrm{b}} \mathrm{O}_{\mathrm{c}}$ & & $\mathrm{Fe}_{\mathrm{a}} \mathrm{C}_{\mathrm{b}} \mathrm{O}_{\mathrm{c}}$ & \\
\hline 27 & 1: $\mathrm{Pb}_{\mathrm{a}} \mathrm{O}_{\mathrm{b}}$ & 2: $\mathrm{Pb}_{\mathrm{a}} \mathrm{Ca}_{\mathrm{b}} \mathrm{Si}_{\mathrm{c}} \mathrm{O}_{\mathrm{d}}$ & 3: $\mathrm{Ca}_{\mathrm{a}} \mathrm{Pb}_{\mathrm{b}} \mathrm{Fe}_{\mathrm{c}} \mathrm{O}_{\mathrm{d}}$ & $\mathrm{Ba}_{\mathrm{a}} \mathrm{S}_{\mathrm{b}} \mathrm{O}_{\mathrm{c}}$ & \\
\hline 28 & $\mathrm{~Pb}_{\mathrm{a}} \mathrm{Si}_{\mathrm{b}} \mathrm{O}_{\mathrm{c}}$ & & & 2: $\mathrm{Fe}_{\mathrm{a}} \mathrm{Ca}_{\mathrm{b}} \mathrm{Si}_{\mathrm{c}} \mathrm{O}_{\mathrm{d}}$ & 3: $\mathrm{Mg}_{\mathrm{a}} \mathrm{Al}_{\mathrm{b}} \mathrm{Si}_{\mathrm{c}} \mathrm{O}_{\mathrm{d}}$ \\
\hline 29 & $\mathrm{~Pb}_{\mathrm{a}} \mathrm{Sb}_{\mathrm{b}} \mathrm{C}_{\mathrm{c}} \mathrm{O}_{\mathrm{d}}$ & & & 2: $\mathrm{K}_{\mathrm{a}} \mathrm{Na}_{\mathrm{b}} \mathrm{Al}_{\mathrm{c}} \mathrm{Si}_{\mathrm{d}} \mathrm{O}_{\mathrm{e}}$ & \\
\hline 30 & $\mathrm{Sn}_{\mathrm{a}} \mathrm{Fe}_{\mathrm{b}} \mathrm{O}_{\mathrm{c}}$ & & & 2: $\mathrm{Ca}_{\mathrm{a}} \mathrm{P}_{\mathrm{b}} \mathrm{O}_{\mathrm{c}}$ & 3: $\mathrm{Ca}_{\mathrm{a}} \mathrm{O}_{\mathrm{b}} \quad$ 4: $\mathrm{Ca}_{\mathrm{a}} \mathrm{Fe}_{\mathrm{b}} \mathrm{O}_{\mathrm{c}}$ \\
\hline 31 & $\mathrm{Sn}_{\mathrm{a}} \mathrm{Fe}_{\mathrm{b}} \mathrm{O}_{\mathrm{c}}$ & & & 2: $\mathrm{Fe}_{\mathrm{a}} \mathrm{Al}_{\mathrm{b}} \mathrm{Si}_{\mathrm{c}} \mathrm{O}_{\mathrm{d}}$ & \\
\hline 32 & $\mathrm{Zn}_{\mathrm{a}} \mathrm{Fe}_{\mathrm{b}} \mathrm{C}_{\mathrm{c}} \mathrm{O}_{\mathrm{d}}$ & & & 2: $\mathrm{Ca}_{\mathrm{a}} \mathrm{C}_{\mathrm{b}} \mathrm{O}_{\mathrm{c}}$ & \\
\hline 33 & 1: $\mathrm{Zn}_{\mathrm{a}} \mathrm{Fe}_{\mathrm{b}} \mathrm{O}_{\mathrm{c}}$ & 2: $\mathrm{Sn}_{\mathrm{a}} \mathrm{Fe}_{\mathrm{b}} \mathrm{O}_{\mathrm{c}}$ & & 2: $\mathrm{Na}_{\mathrm{a}} \mathrm{Al}_{\mathrm{b}} \mathrm{Si}_{\mathrm{c}} \mathrm{O}_{\mathrm{d}}$ & \\
\hline 34 & 1: $\mathrm{Sn}_{\mathrm{a}} \mathrm{O}_{\mathrm{b}}$ & 2: $\mathrm{Sn}_{\mathrm{a}} \mathrm{Ca}_{\mathrm{b}} \mathrm{O}_{\mathrm{c}}$ & 3: $\mathrm{Sn}_{\mathrm{a}} \mathrm{Fe}_{\mathrm{b}} \mathrm{O}_{\mathrm{c}}$ & 2: $\mathrm{Fe}_{\mathrm{a}} \mathrm{O}_{\mathrm{b}}$ & \\
\hline 35 & 1: $\mathrm{Cu}_{\mathrm{a}} \mathrm{O}_{\mathrm{b}}$ & 2: $\mathrm{Zn}_{\mathrm{a}} \mathrm{Si}_{\mathrm{b}} \mathrm{Ca}_{\mathrm{c}} \mathrm{O}_{\mathrm{d}}$ & & 1: $\mathrm{Ca}_{\mathrm{a}} \mathrm{P}_{\mathrm{b}} \mathrm{O}_{\mathrm{c}}$ & \\
\hline 36 & 1: $\mathrm{Pb}_{\mathrm{a}} \mathrm{C}_{\mathrm{b}} \mathrm{O}_{\mathrm{c}}$ & 2: $\mathrm{Pb}_{\mathrm{a}} \mathrm{Sb}_{\mathrm{b}} \mathrm{Sn}_{\mathrm{c}} \mathrm{O}_{\mathrm{d}} \mathrm{C}_{\mathrm{e}}$ & & $\mathrm{K}_{\mathrm{a}} \mathrm{Na}_{\mathrm{b}} \mathrm{Al}_{\mathrm{c}} \mathrm{Si}_{\mathrm{d}} \mathrm{O}_{\mathrm{e}}$ & \\
\hline 37 & 1: $\mathrm{Pb}_{\mathrm{a}} \mathrm{C}_{\mathrm{b}} \mathrm{O}_{\mathrm{c}}$ & 2: $\mathrm{Pb}_{\mathrm{a}} \mathrm{Fe}_{\mathrm{b}} \mathrm{O}_{\mathrm{c}} \mathrm{C}_{\mathrm{d}}$ & & 2: $\mathrm{Na}_{\mathrm{a}} \mathrm{Al}_{\mathrm{b}} \mathrm{Si}_{\mathrm{c}} \mathrm{O}_{\mathrm{d}}$ & \\
\hline 38 & 1: $\mathrm{Sn}_{\mathrm{a}} \mathrm{Fe}_{\mathrm{b}} \mathrm{C}_{\mathrm{c}} \mathrm{O}_{\mathrm{d}}$ & 2: $\mathrm{Sn}_{\mathrm{a}} \mathrm{Fe}_{\mathrm{b}} \mathrm{O}_{\mathrm{c}}$ & & 2: $\mathrm{Ca}_{\mathrm{a}} \mathrm{C}_{\mathrm{b}} \mathrm{O}_{\mathrm{c}}$ & \\
\hline
\end{tabular}

1, 2, 3 and 4: Number of mineralogical phases.

metallic concentrates were removed from the $1-2 \mathrm{~mm}$ and the $0.250-1 \mathrm{~mm}$ attrition scrubbed soil fractions respectively.

For the 1-2 mm soil fraction, it can be observed that $\mathrm{Pb}, \mathrm{Cu}$, and $\mathrm{Sn}$ were highly concentrated in the heaviest fraction. The final concentration measured in the concentrate was $3510 \pm 750 \mathrm{mg} \mathrm{kg}^{-1}$ for $\mathrm{Cu}, 8290 \pm 1070 \mathrm{mg} \mathrm{kg}^{-1}$ for $\mathrm{Pb}$ and $2360 \pm 510 \mathrm{mg} \mathrm{kg}^{-1}$ for $\mathrm{Sn}$,. High metal removals were realized when using dense media separation, varying from $75 \%$ to $89 \%$, depending on the contaminant. However, the efficiency in isolating $\mathrm{Zn}$ from uncontaminated particles was slightly limited. The analysis of the light fraction (between 1.5 and $2.9 \mathrm{~g} \mathrm{~cm}^{-3}$ ) generated by dense media separation method showed that the concentration of $\mathrm{Zn}$ remained relatively high $\left(702 \pm 54 \mathrm{mg} \mathrm{kg}^{-1}\right)$. Dense media separation allowed the removal of $43.1 \%$ of $\mathrm{Zn}$ from the $1-2 \mathrm{~mm}$ fraction of the soil. The removal percent was considered low compared to that obtained for $\mathrm{Cu}, \mathrm{Pb}$ and $\mathrm{Sn}(>75.1 \%)$. The same behavior was observed in another study performed on soil contaminated by municipal solid waste incinerator residues (Jobin et al., 2016b). As discussed in section 3-1, contaminated particles have a very heterogeneous mineralogy. The mineralogy of both heavy metal and carrying phase with which the metal is embedded or adsorbed controls the fate of the contaminated particle during the gravimetric separation process (Dermont et al., 2008; Mercier et al., 2001). Likewise, the surface percentage of each mineralogical phase present in the particle defines the mean density of this latter and consequently its response to the force of gravity (Mercier et al., 2001). The loss of efficiency in separating $\mathrm{Zn}$ by using dense me- dia separation reflects the fact that a large proportion of Zn-particles is distributed in a range of a mean density inferior to $2.9 \mathrm{~g} \mathrm{~cm}^{-3}$. This can be explained by the fact than $\mathrm{Zn}$ is for instance in silicate $\left(\mathrm{Zn}_{2} \mathrm{SiO}_{4}\right)$ or $\mathrm{Zn}$-aluminate $\left(\mathrm{ZnAl}_{2} \mathrm{O}_{4}\right)$ forms, as reported in another study (Abanades et al., 2002) and adsorbed to a light matrix (for example silicate glass matrix with a mean density of $2.64 \mathrm{~g} \mathrm{~cm}^{-3}$ ) (Wei et al., 2011). If the matrix occupies a large area of the particle, the mean density of the contaminated particle will be consequently reduced. This negatively affects the response of $\mathrm{Zn}$ to the gravimetric separation. It must be noted that the presence of such matrix $\left(\mathrm{Na}_{\mathrm{a}} \mathrm{Al}_{\mathrm{b}} \mathrm{Si}_{\mathrm{c}} \mathrm{O}_{\mathrm{d}}, \mathrm{K}_{\mathrm{a}} \mathrm{Si}_{\mathrm{b}} \mathrm{O}_{\mathrm{c}}\right)$ was found among heavy particles (density $>2.9 \mathrm{~g} \mathrm{~cm}^{-3}$ ) (Table 2). However, these particles were separated by the dense media method since this mineralogical phase was associated to other heavy phases (for example, $\mathrm{Fe}_{\mathrm{a}} \mathrm{O}_{\mathrm{b}}$ or $\mathrm{Sn}_{\mathrm{a}} \mathrm{Fe}_{\mathrm{b}} \mathrm{O}_{\mathrm{c}}$ ).

For the $0.250-1 \mathrm{~mm}$ soil fraction, dense media separation allowed for high concentrations of $\mathrm{Pb}, \mathrm{Cu}$, and $\mathrm{Sn}$ in the heaviest fraction. Metal removal yields varied from $47.5 \%$ to $94.7 \%$, depending on the contaminant considered. $\mathrm{Zn}$ was less concentrated in the light fraction. However, as observed for the 1-2 mm fraction, the $\mathrm{Zn}$ concentration remained relatively high $\left(593 \pm 51 \mathrm{mg} \mathrm{kg}^{-1}\right)$. The metal was moderately removed $(46.3 \%)$ from the $0.250-1 \mathrm{~mm}$ fraction. The good efficiency of dense media separation in removing $\mathrm{Pb}, \mathrm{Cu}$ and $\mathrm{Sn}$ was reported in previous studies. $\mathrm{Pb}, \mathrm{Cu}$, and $\mathrm{Sn}$ removals were higher than $80 \%$ (Mercier et al., 2001). Indeed, the dense media separation method is known for its separation accuracy since only the forces of gravity and buoyancy affect the sedimentation of each soil 




a.





b.




of $\mathrm{Ca}$.

Table 3

Densimetric analysis of the feedstock by using tetrabromoethane.

\begin{tabular}{|c|c|c|c|c|c|}
\hline \multirow[t]{2}{*}{ Parameter } & \multirow[t]{2}{*}{ Mass $(\%)$} & \multicolumn{4}{|c|}{ Metallic contaminants (mg. $\mathrm{kg}^{-1}$ ) } \\
\hline & & $\mathrm{Cu}$ & $\mathrm{Pb}$ & $\mathrm{Sn}$ & $\mathrm{Zn}$ \\
\hline \multicolumn{6}{|c|}{ Fraction 1-2 mm } \\
\hline Initial & 100 & & & & \\
\hline$<1.50 \mathrm{~g} \mathrm{~cm}^{-3}$ & $0.65 \pm 0.5$ & $721 \pm 113$ & $886 \pm 151$ & $91.5 \pm 12.2$ & $1205 \pm 240$ \\
\hline $\begin{array}{l}\text { Between } 1.50 \\
\text { and } \\
2.89 \mathrm{~g} \mathrm{~cm}^{-3}\end{array}$ & $82.5 \pm 0.3$ & $198 \pm 15$ & $453 \pm 40$ & $76.5 \pm 15.6$ & $702 \pm 54$ \\
\hline$>2.89 \mathrm{~g} \mathrm{~cm}^{-3}$ & $16.0 \pm 1.5$ & $3510 \pm 750$ & $8290 \pm 1070$ & $2360 \pm 510$ & $3630 \pm 580$ \\
\hline $\begin{array}{l}\text { Massic } \\
\text { removal } \\
(\%)\end{array}$ & 17.5 & 75.1 & 80.6 & 88.6 & $43.1-$ \\
\hline \multicolumn{6}{|c|}{ Fraction $0.250-1 \mathrm{~mm}$} \\
\hline Initial & 100 & & & & \\
\hline$<2.89 \mathrm{~g} \mathrm{~cm}^{-3}$ & $86.9 \pm 1.9$ & $208 \pm 18$ & $509 \pm 25$ & $37.2 \pm 10.4$ & $593 \pm 51$ \\
\hline$>2.89 \mathrm{~g} \mathrm{~cm}^{-3}$ & $14.9 \pm 1.4$ & $1180 \pm 185$ & $7290 \pm 100$ & $1930 \pm 780$ & $2300 \pm 150$ \\
\hline $\begin{array}{l}\text { Massic } \\
\text { removal } \\
(\%)\end{array}$ & 13.1 & 47.5 & $\mathbf{5 7 . 8}$ & $94.7-2$ & 46.3 \\
\hline
\end{tabular}

particle (Drzymała and Swatek, 2007). To conclude, the presence of the two first classes (totally liberated particles and contaminants associated with the heavy phase) and the high-to-medium release availability of the contamination according to the light carrying phase, coupled with the dense media separation results, supported the selection of gravimetric technology to treat soil fractions contaminated by $\mathrm{Pb}$, $\mathrm{Cu}$, and $\mathrm{Sn}$. However, the gravimetric treatment of $\mathrm{Zn}$ was not conducted in the remaining part of the study. A special concern must be allocated to $\mathrm{Zn}$ according to further deep investigations in order to select the appropriate strategy of separation.

\subsection{Gravimetric treatment of the 1-2 mm fraction}

\subsubsection{Preliminary assays}

As mentioned in Section 2.3.2, preliminary assays were conducted using a control soil in order to select the main variables affecting the gravimetric treatment with the shaking table device. Fig. 3-a shows the effect of the solid throughput on the mass collected at several exits of the table. The corresponding densities of each collected mass appear in Fig. 3-b. Varying the throughput of the solid from 50 to $300 \mathrm{~g} \mathrm{~m}^{-3}$ increased the solid-liquid ratio from $0.6 \%$ to $4.0 \%$. Increasing the proportion of the solid is known to hinder the settling effect, and consequently, the density classification (Wills, 2011). However, as the collected masses and densities were similar for the different assays, no significant effect was observed when the throughput of the solid was varied. The solid throughput was consequently fixed while studying the effects of the shaking table variables.

On the other hand, Fig. 3-c shows the relationship between the stroke frequency and stroke length. For the tests conducted at the maximum and minimum stroke frequencies $\left(500 \mathrm{strokes} \cdot \mathrm{min}^{-1}\right.$ and 250 strokes $\cdot \mathrm{min}^{-1}$ respectively), the variables remained constant when the stroke length varied from $11 \mathrm{~mm}$ to $14 \mathrm{~mm}$. Therefore, the stroke frequency and stroke length are independent parameters, and their effects on the motion of the particles in the deck can be studied using a Box-Behnken methodology.

\subsubsection{Box-Behnken statistical analysis (ANOVA)}

The fitness of the mathematical models developed was assessed using the analysis of variance (ANOVA). Graphical examinations of the plot of the normal probability of residuals, the plot of residuals versus the experimental run order and the plot of residuals versus pre- 
a-


b-


C-


Minimum stroke frequency
Maximum stroke frequency




particles at $\mathrm{E} 1, \mathrm{E}(2: 3)$, and $\mathrm{E}(4,5,6,7)$. 2-c: Relationship between stroke length and stroke frequency.

dicted verified the assumptions of normal distribution of residues and their independency with a constant variance. The ANOVA provided information about the contribution of the tilt (A), the washing water flow (B), the stroke length (C) and the stroke frequency (D) or of their factorial interaction to the variation in each response (RE, density of the concentrate, $\mathrm{R}_{M}(\mathrm{~Pb}), \mathrm{R}_{\mathrm{M}}(\mathrm{Cu})$ and $\left.\mathrm{R}_{\mathrm{M}}(\mathrm{Sn})\right)$. The significance of this contribution was tested according the F-test within a $95 \%$ confidence interval. The different results of ANOVA are detailed in Supplementary Table 1. The sum of square, the degree of freedom, the mean square, the F-value and the $p$-value were calculated for each model and for each factor of the statistical model. Table 4 highlights the main results obtained. The developed models and the factors of the shaking table are significant if the value of "Prob $>F$ " is lower than 0.05 . The fit summary of the output indicated that all the established models were statistically significant ( $p$-values $<0.0001$ ). The adequacy of models was also checked by the analysis of the regression coefficients $\left(\mathrm{R}^{2}\right)$ and the adequate precision. The adjusted $\mathrm{R}^{2}$ indicates the amount of the variation explained 
Table 4

Main results of the ANOVA performed on the mathematical models.

\begin{tabular}{llllll}
\hline Sources & $\mathrm{R}_{\mathrm{E}}{ }^{\mathrm{a}}$ & $\begin{array}{l}\text { Density of the } \\
\text { concentrate }\end{array}$ & $\mathrm{R}_{\mathrm{M}}{ }^{\mathrm{b}}(\mathrm{Pb})$ & $\mathrm{R}_{\mathrm{M}}(\mathrm{Cu})$ & $\mathrm{R}_{\mathrm{M}}(\mathrm{Sn})$ \\
\hline $\mathrm{p}$-value & $<0.0001$ & $<0.0001$ & $<0.0001$ & $<0.0001$ & $<0.0001$ \\
$\mathrm{R}^{2}$ & & & & & \\
Adjusted $^{2}$ & 0.96 & 0.84 & 0.86 & 0.84 & 0.88 \\
Predicted $\mathrm{R}^{2}$ & 0.89 & 0.78 & 0.79 & 0.72 & 0.75 \\
$\mathrm{CV}$ & 21.3 & 10.7 & 10.5 & 19.5 & 19.7 \\
$\begin{array}{l}\text { Adequate } \\
\text { precision }\end{array}$ & 23.4 & 13.3 & 16.4 & 15.2 & 16.1 \\
\hline
\end{tabular}

${ }^{\mathrm{a}} R_{E}=$ Removal efficiency.

${ }^{b} R_{M}=$ Metal Removal efficiency.

by the models after the adjustment of their terms. The predicted $\mathrm{R}^{2}$ indicates how well models predict new observations (Jordão et al., 2016). The adequate precision is a signal to noise ratio. It compares the range of the predicted values to the average prediction error (Mocellin et al., 2015). Consequently, a high adjusted $\mathrm{R}^{2}$, a low difference between adjusted and predicted $\mathrm{R}^{2}$ and an adequate precision higher than 4 are favored (Tanong et al., 2016). The adjusted $\mathrm{R}^{2}$ and the predicted $\mathrm{R}^{2}$ were superior than 0.84 , indicating that less than $16 \%$ of the 29 experimental values could not be explained using the mathematical models. The coefficient of variance ranged from $10.7 \%$ to $21.6 \%$, which pointed to the models reliability being either high or acceptable. The adequate precision of each proposed model was desirable (the signal to noise ratio was higher than 4). In addition, the lack of fit was not significant, indicating that the mathematical models established a good fit with the experimental values. Supplementary Fig. 1 illustrates the relationship between the predicted and experimental values. The diagnostic of the predicted versus experimental values supports that models were suitable for predicting RE, the density of the concentrate, $\mathrm{R}_{\mathrm{M}}(\mathrm{Pb}), \mathrm{R}_{\mathrm{M}}(\mathrm{Cu})$ and $\mathrm{R}_{\mathrm{M}}(\mathrm{Sn})$ in the experimental field studied.

As observed in Supplementary Table 1, the calculation of $p$-values demonstrates that factors $\mathrm{A}, \mathrm{B}, \mathrm{BD}, \mathrm{A}^{2}$ and $\mathrm{B}^{2}$ had a significant influence on the response RE. The factors $\mathrm{A}, \mathrm{B}, \mathrm{AB}$, and $\mathrm{CD}$ had a significant influence on the density of the concentrate. The factors A, B, C, $\mathrm{BD}, \mathrm{A}^{2}$ and $\mathrm{B}^{2}$ had a significant effect on $\mathrm{R}_{\mathrm{M}}(\mathrm{Pb})$. The factors $\mathrm{A}, \mathrm{B}$, $C$, and $A^{2}$ were statically significant for $R_{M}(C u)$. Finally, $A, B, C D$, $\mathrm{A}^{2}$ and $\mathrm{B}^{2}$ had a significant influence on $\mathrm{R}_{\mathrm{M}}(\mathrm{Sn})$.

Equations (8-a) to (8-e) show, for each response, the mathematical model expressed in terms of coded factors. The comparison of the coefficients of each factor highlighted that tilt (A) and washing water flow (B) had the highest impact on RE, the density of the concentrate, $R_{M}(P b), R_{M}(C u)$, and $R_{M}(S n)$. The signs of these coefficients revealed whether each factor increases (positive sign) or decreases (negative sign) the studied response (Jin et al., 2014). According to Equations (8-a) to (8-e), both tilt (A) and washing water flow (B) had a positive influence on the density of the concentrate and a negative influence on RE. This indicated that increasing tilt and/or washing water flow will lead to a decrease in RE and an increase in the density of the concentrate.

$$
\begin{aligned}
R E & =0.63-2.30 \\
& * A-1.65 \\
& * B-0.03 \\
& * C-0.05 \\
& * D+0.23 \\
& * A \\
& * C+0.37 \\
& * A \\
& * D-0.53 \\
& * B \\
& * D+2.06 \\
& * A^{2}+1.38 \\
& * B^{2}
\end{aligned}
$$

Density of concentrate

$=4.01+1.17$

$* A+1.10$

$* B+0.23$

* $C+0.05$

* $D+0.92$

* $A$

$* B+0.23$

* $A$

* $C+0.59$

$* C$

$* D$

$R M(P b)=0.72-0.26$

* $A-0.19$

* B-0.09

$* C-0.01$

* D-0.05

$* B$

$* C-0.09$

$* B$

$* D+0.20$

$* A^{2}+0.08$

$* B^{2}$ 


$$
\begin{aligned}
R M(C u) & =0.58-0.42 \\
& * A-0.26 \\
& * B-0.12 \\
& * C-0.03 \\
& * D-0.13 \\
& * C \\
& * D+0.20 \\
& * A^{2}+0.14 \\
& * B^{2}
\end{aligned}
$$

$$
\begin{aligned}
R M(S n) & =0.49-0.42 \\
& * A-0.28 \\
& * B-0.07 \\
& * C+0.001 \\
& * D-0.07 \\
& * B \\
& * D-0.20 \\
& * C \\
& * D+0.17 \\
& * A^{2}+0.11 \\
& * B^{2}+0.07 \\
& * C^{2}
\end{aligned}
$$

\subsubsection{Effect of shaking table factors on the treatment of the 1-2 $\mathrm{mm}$ soil fraction}

Contour plots, presented in Fig. 4, were constructed to demonstrate the effect of tilt (A) and washing water flow (B) on RE, $R_{M}(P b)$, $\mathrm{R}_{\mathrm{M}}(\mathrm{Cu}), \mathrm{R}_{\mathrm{M}}(\mathrm{Sn})$, and on the density of the concentrate. As mentioned previously, both tilt and washing water flow are the main factors influencing the various responses studied. The influence of these parameters on the mass of the concentrate as well as metal removal efficiencies $\left(R_{M}(M)\right)$ seemed to be negative. However, these parameters had positive effects on the density of the concentrate, which was indicative of the degree of the concentrate's purity. Lowering the tilt levels led to results close to those obtained by dense media separation in terms of metal removal efficiencies, where $R_{M}(P b), R_{M}(C u)$, and $\mathrm{R}_{\mathrm{M}}(\mathrm{Sn})$ tended towards 1 . Lowering the tilt generally ensures a good distribution of material on the shaking table and maximizes the separation process (Mehrotra and Singhal, 2000). However, according to the RE plot, decreasing the tilt to beyond $10^{\circ}$ can promote the particle mass to move excessively to exits E4, E5, E6, and E7 ( RE > 1). Consequently, the density of the collected mass at the concentrate zone decreases to less than $3.5 \mathrm{~g} \mathrm{~cm}^{-3}$. Therefore, to ensure removal of the mass of the concentrate similar to that obtained by dense media separation, a slight loss of metal removal efficiencies $\left(R_{M}(M)\right)$ has to be tolerated. In fact, a particle density difference greater than $1 \mathrm{~g} \mathrm{~cm}^{-3}$ is theoretically required for the separation process, and several factors are involved, including particle size distribution and shape (Dermont et al., 2008). Additionally, the acting forces that occur during the operation of the shaking table are more complex than those occurring during dense media separation. In addition to the gravity and buoyancy forces, forces due to the table motion and the flowing film of water play an important role on the mo- tion of particles through the deck (Wills, 2011). In order to reach good separation at low tilt levels, higher washing water flows are necessary. Hence, tilting the deck to between $10.5^{\circ}$ and $12^{\circ}$ and setting the washing water flow to between 5 and $8 \mathrm{~L} \mathrm{~min}^{-1}$ led to an RE close to 1 . Under these conditions, $\mathrm{R}_{\mathrm{M}}(\mathrm{Pb}), \mathrm{R}_{\mathrm{M}}(\mathrm{Cu})$, and $\mathrm{R}_{\mathrm{M}}(\mathrm{Sn})$ are higher than 0.6. An acceptable purity of the concentrate can be also obtained with a density exceeding $3.5 \mathrm{~g} \mathrm{~cm}^{-3}$. Therefore, the concentration of metals can be maximized at the lowest volume of concentrate.

Fig. 5 illustrates the effect of both stroke length (C) and frequency (D) on $\mathrm{R}_{\mathrm{M}}(\mathrm{Pb}), \mathrm{R}_{\mathrm{M}}(\mathrm{Cu})$, and $\mathrm{R}_{\mathrm{M}}(\mathrm{Sn})$. Stroke length and frequency are generally involved in selective particle motion, by bed dilation and stratification (Mehrotra and Singhal, 2000). According to these results, the stroke length appeared to have a negative impact on $\mathrm{R}_{\mathrm{M}}(\mathrm{Pb})$, $\mathrm{R}_{\mathrm{M}}(\mathrm{Cu})$, and $\mathrm{R}_{\mathrm{M}}(\mathrm{Sn})$. Lowering the stroke length led to an increase in metal removal efficiencies. The operating conditions of stroke length must vary from 11 to $12 \mathrm{~mm}$ to produce results close to those obtained by dense media separation. The interaction between stroke length and stroke frequency has also been studied. A decrease of the stroke length and an increase of the stroke frequency are required to raise the shaking table's efficiency of $\mathrm{Cu}$ and $\mathrm{Sn}$ removal from uncontaminated particles and to obtain results similar to dense media separation $\left(\mathrm{R}_{\mathrm{M}}(\mathrm{Cu})\right.$ and $\mathrm{R}_{\mathrm{M}}(\mathrm{Sn})$ should be close to 1$)$. Observations of the effect of stroke frequency on mass removal of the concentrate highlighted that a very large decrease in stroke length can significantly promote the exit of particles of the concentrate zone $(\mathrm{RE}>1)$. It appeared that lowering the stroke length and frequency is necessary for the removal of $\mathrm{Pb}$ from uncontaminated particles. $\mathrm{R}_{\mathrm{M}}(\mathrm{Pb})$ tended to 1 under such operating conditions. In summary, according to the results presented in Fig. 5, the recommended operating conditions of stroke frequency should be between 350 and 400 strokes $\cdot \mathrm{min}^{-1}$ to maximize $\mathrm{Cu}$ and Sn removals, whereas these values should be between 300 and 400 strokes $\cdot \mathrm{min}^{-1}$ to maximize the removal of $\mathrm{Pb}$.

\subsubsection{Process optimization}

Polynomial equations use multiple linear regressions to identify which optimal operational parameters can improve the performance of the shaking table with regard to the removal of $\mathrm{Cu}, \mathrm{Pb}$, and $\mathrm{Sn}$ from uncontaminated particles and concentrating these contaminants within the smallest possible volume. Tilt, washing water flow, stroke length, and frequency were set at $10.5^{\circ}, 6.1 \mathrm{~L} \mathrm{~min}^{-1}, 11 \mathrm{~mm}$, and 432 strokes $\cdot \mathrm{min}^{-1}$ respectively. Table 5 presents the predicted and experimental results of $R E$, density of the concentrate, $R_{M}(P b), R_{M}(C u)$, and $\mathrm{R}_{\mathrm{M}}(\mathrm{Sn})$ obtained during the validation experiments performed under the optimal conditions described previously. Firstly, it can be observed that experimental RE were close to 1 , which reflected a satisfactory mass removal of the concentrate. It corresponded to $20.8 \%$ $\left(\mathrm{w} \cdot \mathrm{w}^{-1}\right)$ of the total mass of the soil sample initially used for the experiment. The recovered concentrate was characterized by an acceptable purity, with a density of $3.32 \mathrm{~g} \mathrm{~cm}^{-3}$. The experimental results obtained for $\mathrm{R}_{\mathrm{M}}(\mathrm{Pb})$ and $\mathrm{R}_{\mathrm{M}}(\mathrm{Cu})$ were 0.8 for $\mathrm{Pb}$ and 0.7 for $\mathrm{Cu}$, which corresponded to $67.3 \%$ and to $54.5 \%$ of $\mathrm{Pb}$ and $\mathrm{Cu}$ removals respectively. A lower $R_{M}$ than those predicted was obtained $\left(\mathrm{R}_{\mathrm{M}}(\mathrm{Sn})=0.6\right)$ for the removal of $\mathrm{Sn}$, corresponding to a removal of $54.5 \%$. It must be noted that the experimental results were slightly lower than predicted. This reflected the impact of the experimental error relative to the predictive models. For instance, as seen for the removal of $\mathrm{Sn}$, the corresponding $\mathrm{CV}$ was around $20 \%$, which may explain the difference between the experimental and predicted values. However, despite this difference, the mathematical models established were useful to predict the behavior of the shaking table and its 

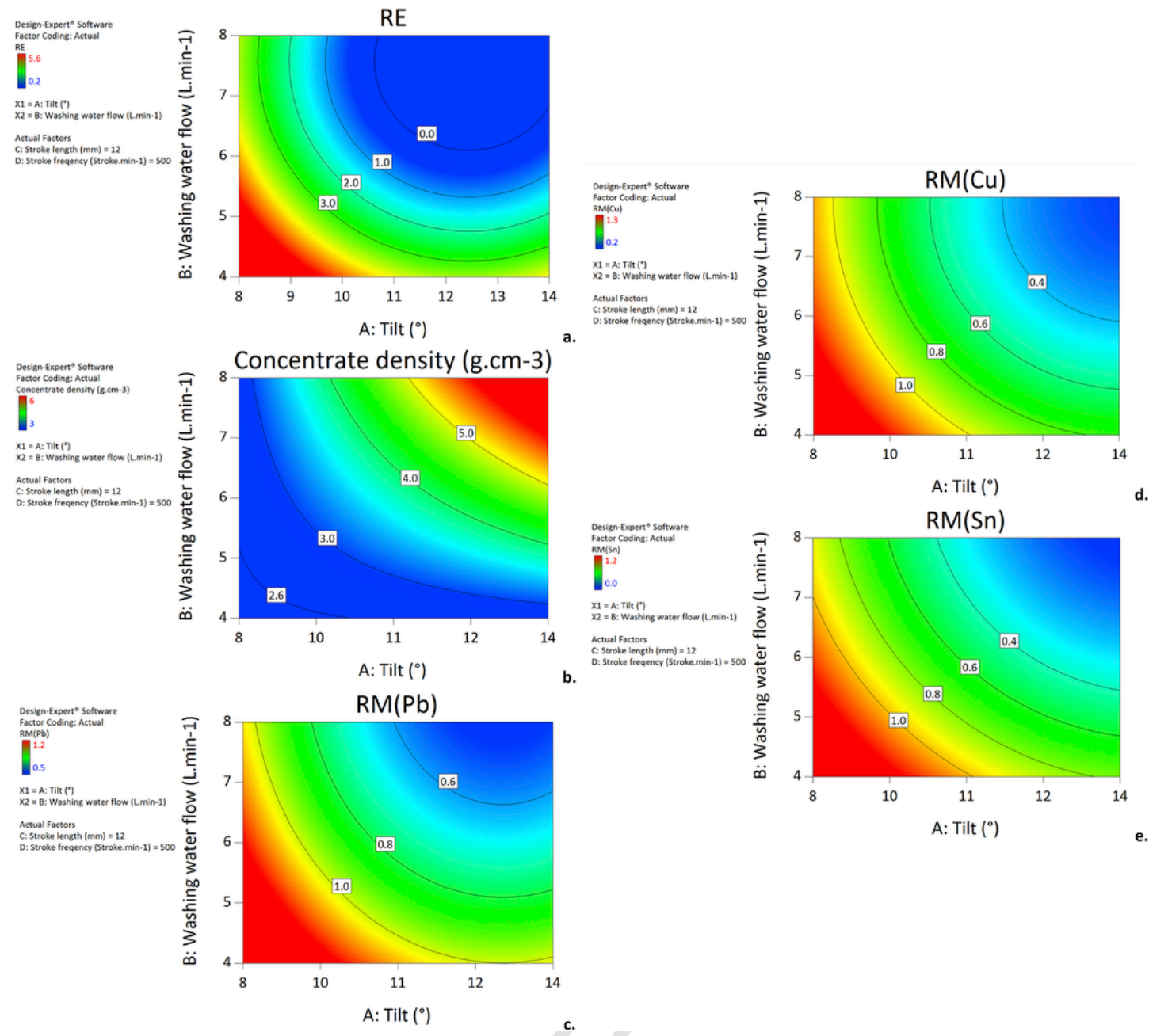
a.


Fig. 4. Effect of tilt and washing water flow on $R E$, density of the concentrate, $R_{M}(P b), R_{M}(C u)$, and $R_{M}(S n)$.

performance, and to maximize the gravimetric separation when using the shaking table.

\subsection{Movement study and gravimetric treatment of the fine soil fraction $(0.250-1 \mathrm{~mm})$}

As explained before, the reliability of the mathematical model regarding the mass movement of the concentrate was demonstrated (the predicted and experimental RE values were similar). The model was then taken through five combinations of shaking table operating factors to check their effects on the motion of the fine-sized soil particles $(0.250-1 \mathrm{~mm})$ on the deck. The results obtained from the $0.250-1 \mathrm{~mm}$ soil fraction and the predicted values estimated by the mathematical models for the same fraction were compared for different settings of the operational conditions. Hence, Fig. 6 was plotted in order to understand if the observations made regarding the $1-2 \mathrm{~mm}$ soil fraction can be extrapolated to the $0.250-1 \mathrm{~mm}$ soil fraction. This figure presents the results (theoretical mass of medium-sized particles (1-2 $\mathrm{mm})$ and experimental mass of the fine-sized particles $(0.250-1 \mathrm{~mm}))$ obtained from the concentrate collecting zone and under selected conditions. Details of the setting conditions are mentioned in Fig. 6. Conditions 1, 2, 3, 4, and 5 are detailed in the legend of Fig. 6. They were selected according to the established statistical model, because they gradually allow for an increase of the mass of the concentrate collected from the 1-2 mm soil fraction. According to Fig. 6, the conditions 1, 2, 3 and 5 ensured a gradual increase of the mass removed from the $1-2 \mathrm{~mm}$ fraction. Likewise, a similar tendency was observed in the case of the $0.250-1 \mathrm{~mm}$ soil fraction. The collected mass of $0.250-1 \mathrm{~mm}$ particles increased from 3.0 to $95 \%$ under the series of conditions 1 to 5 . The optimal condition (condition 3) was defined to effectively separate metals from uncontaminated particles for the $1-2 \mathrm{~mm}$ fraction. However, it led to a lower mass removal in the case of the $0.250-1 \mathrm{~mm}$ fraction of soil. Additionally, the condition 3 separated a lower mass of concentrate from the $0.250-1 \mathrm{~mm}$ fraction than that separated by using dense media separation $(\mathrm{RE}=0.54)$. The effective treatment of the fine fraction consequently needed other adjustments of the shaking table variables. Except for the condition 5, the conditions 1,2 and 4 led to a lower mass of concentrate for the $0.250-1 \mathrm{~mm}$ soil fraction compared to the results predicted for the $1-2 \mathrm{~mm}$ soil fraction. The condition 5 promoted the total feedstock to reach the end of the deck and move to exits E4, E5, E6, and E7, indicating the limit of the separation process. Consequently, the statistical model developed during this study is appropriate for one specific contaminated matrix with specific physical, chemical and mineralogical properties.

According to the results presented Table 6 , condition 4 (tilt: $11^{\circ}$, stroke length: $11 \mathrm{~mm}$, stroke frequency: 352 strokes $\cdot \mathrm{min}^{-1}$, and washing water flow: $5 \mathrm{~L} \mathrm{~min}^{-1}$ ) led to a satisfying mass removal of the 




Fig. 5. 5-a: Effect of washing water flow and stroke frequency on RE. 5-b, 5-c, and 5-d: Effect of stroke length and stroke frequency on $R_{M}(P b), R_{M}(C u)$, and $R_{M}(S n)$ respectively.
Table 5

Comparison of the predicted values and the experimental values using optimal conditions defined using Expert Design 8.0

\begin{tabular}{|c|c|c|c|c|c|}
\hline & $\mathrm{R}_{\mathrm{E}}$ & $\begin{array}{l}\text { Density of } \\
\text { concentrate }\end{array}$ & $\mathrm{R}_{\mathrm{M}}(\mathrm{Pb})$ & $\mathrm{R}_{\mathrm{M}}(\mathrm{Cu})$ & $\mathrm{R}_{\mathrm{M}}(\mathrm{Sn})$ \\
\hline Predicted data & 1.00 & 3.50 & 0.80 & 0.80 & 0.80 \\
\hline CV-Model & 21.3 & 10.7 & 10.5 & 19.5 & 19.7 \\
\hline $\begin{array}{l}\text { Experimental } \\
\text { data }\end{array}$ & $1.19 \pm 0.10$ & $3.32 \pm 0.03$ & $0.84 \pm 0.01$ & $0.73 \pm 0.08$ & $0.62 \pm 0.05$ \\
\hline
\end{tabular}

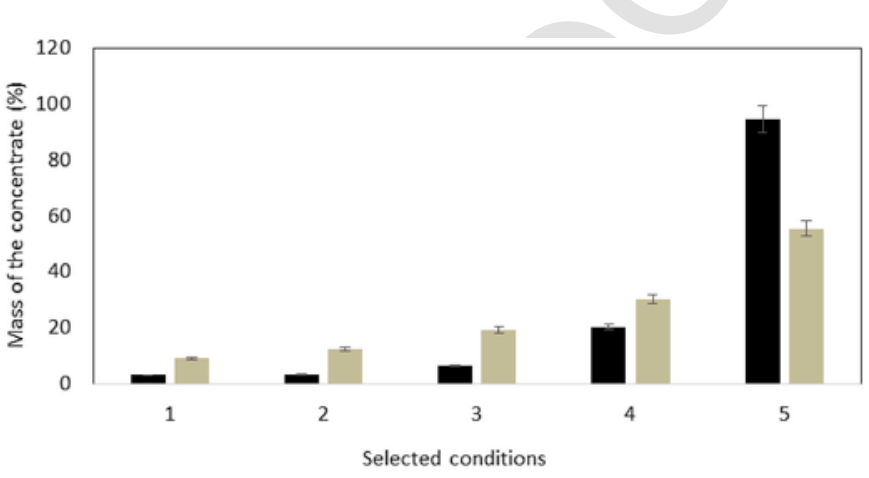

- Experimental removal (0.250-1 mm) = Theorotical removal $(1-2 \mathrm{~mm})$

Fig. 6. Effect of selected conditions on the motion of medium- and fine-sized particles.

Table 6

Physical and chemical results of the treatment of fine particles under condition 4 .

\begin{tabular}{llllll}
\hline Parameter & Density $\left(\mathrm{g} . \mathrm{cm}^{-3}\right)$ & \multicolumn{3}{l}{$\begin{array}{l}\text { Mass } \\
(\%)\end{array}$} & \multicolumn{3}{l}{ Contaminants $\left(\mathrm{mg} . \mathrm{kg}^{-1}\right)$} \\
\hline & & & $\mathrm{Cu}$ & $\mathrm{Pb}$ & $\mathrm{Sn}$ \\
\hline Input & & $\mathbf{1 0 0}$ & 343 & 1040 & 609 \\
E1 & 2.35 & 1.92 & 806 & 1119 & 322 \\
E2 & 2.64 & 40.9 & 384 & 870 & 384 \\
E3 & 2.70 & 49.0 & 193 & 470 & 488 \\
E4 & 3.20 & 2.74 & 729 & 2636 & 1701 \\
E 567 & 3.84 & 6.91 & 890 & 10556 & 2336 \\
Removal according to the mass balance & $\mathbf{1 0 . 0}$ & $\mathbf{2 3 . 6}$ & $\mathbf{4 2 . 7}$ & $\mathbf{3 5 . 2}$ \\
& & & & & \\
\hline
\end{tabular}

concentrate, corresponding to $10 \%$ of the input mass of the $0.250-1 \mathrm{~mm}$ soil fraction, and it was slightly lower than that obtained by dense media separation $(13.1 \%)$. The corresponding density was around $3.63 \mathrm{~g} \mathrm{~cm}^{-3}$, reflecting the appreciated purity of the concentrate produced. This operating condition allowed for a removal of $23.6 \%$ of $\mathrm{Cu}, 42.7 \%$ of $\mathrm{Pb}$, and $35.2 \%$ of $\mathrm{Sn}$. These results were lower than those obtained by dense media separation $(47.5 \%$ of $\mathrm{Cu}, 57.8 \%$ of $\mathrm{Pb}$, and $94.7 \%$ of $\mathrm{Sn}$ ). Through these results, the treatment of $\mathrm{Sn}$ was more efficient for the 1-2 $\mathrm{mm}$ soil fraction than for the $0.250-1 \mathrm{~mm}$ soil fraction. This loss of efficiency observed for the removal of $\mathrm{Sn}$ from uncontaminated particles using a shaking table was previously reported by Jobin et al. (2016a) who observed that $\mathrm{Sn}$ removal from municipal solid waste contaminated soils dropped from $70 \%$ to $51 \%$ when the size of the particles changed from medium to fine. According to the results presented in Table 3 , the presence of particles containing Sn associated with silicate and calcium oxide/carbonate phases can explain these results. Indeed, the mean density of such particles can be lowered, which may hinder their movement to the concentrate zone.

Regarding the use of the shaking table, condition 4 (tilt of $11^{\circ}$, washing water flow of $5 \mathrm{~L} \mathrm{~min}^{-1}$, stroke length of $11 \mathrm{~mm}$, and stroke frequency of 352.2 strokes $\cdot \mathrm{min}^{-1}$ ) appeared to be the optimal condi- 
tion to separate $\mathrm{Cu}$ and $\mathrm{Sn}$ from uncontaminated particles of the $0.250-1 \mathrm{~mm}$ soil fraction. Compared with the $1-2 \mathrm{~mm}$ soil fraction, reductions in the stroke frequency and washing water flow are necessary to improve contaminant removal from the $0.250-1 \mathrm{~mm}$ soil fraction. In fact, reducing the action of these factors induces lower turbulence inside the fluid, and therefore, decreases the coefficient of resistance of the liquid. Hence, according to Equation (9) (expressed for spherical particles), the drag force of the fluid is reduced (Peker and Helvaci, 2011). Fine-sized particles can therefore cross the water film sheet more effectively and move slowly to the concentrate zone.

$$
\text { Drag force of the liquid }=\frac{\pi * d^{2} * C * \rho_{f} * v^{2}}{8}
$$

where $d$ is the diameter of the particle, $C$ is the coefficient of resistance of the fluid (depending on the Reynolds number), $\rho_{f}$ is the volumetric mass density of the fluid, and $v$ is the particle velocity.

Finally, improved understanding of the influence of operational factors and their interactions on the motion of particles from the 1-2 $\mathrm{mm}$ soil fraction allowed for the determination of the most favorable operational conditions to treat the fine-sized particles $(0.250-1 \mathrm{~mm})$ through a single pass on the shaking table. Only the mass of the concentrate and the density were used during the optimization step for the treatment of the $0.250-1 \mathrm{~mm}$ soil fraction, and the number of experiments was reduced from 29 to 5 .

\section{Conclusions}

Densimetric and mineralogical characterization of soils contaminated by the inappropriate management of municipal solid waste incinerator residues revealed the utility and limitations of using gravimetric processes to treat this type of contamination. During the treatment of the soil using dense media separation, $\mathrm{Pb}, \mathrm{Cu}$, and $\mathrm{Sn}$ were highly concentrated in the heavy fraction. The concentration of $\mathrm{Pb}$ varied from $7290 \mathrm{mg} \mathrm{kg}^{-1}$ (fraction $0.250-1 \mathrm{~mm}$ ) to $8290 \mathrm{mg} \mathrm{kg}^{-1}$ (fraction $1-2 \mathrm{~mm}$ ). The concentration of $\mathrm{Cu}$ varied from $1180 \mathrm{mg} \mathrm{kg}^{-1}$ (fraction $0.250-1 \mathrm{~mm}$ ) to $3510 \mathrm{mg} \mathrm{kg}^{-1}$ whereas the concentration of Sn varied form 1930 (fraction $0.250-1 \mathrm{~mm}$ ) to $2360 \mathrm{mg} \mathrm{kg}^{-1}$ (fraction 1-2 $\mathrm{mm}$ ). Whereas it was more difficult to recover $\mathrm{Zn}$ from the uncontaminated matrix. The microscopic investigation demonstrated the mineralogical heterogeneity of the contamination and allowed for the classification of particles into various classes according to their gravimetric response during separation. Completely liberated particles and associated contaminants with heavy phases promote the separation. However, associated contaminants with light phases may negatively affect the separation process and can explain the loss of efficiency observed during the treatment using the shaking table. The shaking table was efficiently used to treat soil contaminated by municipal solid waste incineration residues and to concentrate the contaminants into a smaller volume. For the treatment of the $1-2 \mathrm{~mm}$ soil fraction, $R E$ and $R_{M}(M)$ ratios were calculated in order to define the best shaking table performance. A Box-Behnken methodology was used to establish quadratic mathematical models, to predict $\mathrm{RE}, \mathrm{R}_{\mathrm{M}}(\mathrm{Pb}), \mathrm{R}_{\mathrm{M}}(\mathrm{Cu}), \mathrm{R}_{\mathrm{M}}(\mathrm{Sn})$, and the density of the concentrate depending on the operational conditions used. Tilt and washing water flow appeared to be the main parameters influencing the performance of the shaking table. The established mathematical model demonstrated satisfactory performance in predicting the desired responses (mass and metal removals as well as the density of the concentrate). The following were identified as optimal conditions to remove $\mathrm{Cu}, \mathrm{Pb}$, and $\mathrm{Sn}$ from the $1-2 \mathrm{~mm}$ soil fraction: tilt of $10.5^{\circ}$, washing water flow of $6.1 \mathrm{~L} \mathrm{~min}^{-1}$, stroke length of $11 \mathrm{~mm}$, and stroke frequency of 432 strokes $\cdot \mathrm{min}^{-1}$. These optimal conditions achieved contaminant concentration within a small fraction (corresponding to $20.8 \%\left(\mathrm{w} \cdot \mathrm{w}^{-1}\right)$ of the initial mass of soil to be treated), with a mean density of $3.32 \mathrm{~g} \mathrm{~cm}^{-3}$. The removal yields under these optimal conditions were $67.3 \%, 54.5 \%$, and $54.6 \%$ for $\mathrm{Pb}, \mathrm{Cu}$, and $\mathrm{Sn}$ respectively. Understanding the influence of the operational parameters and their interactions on the motion of the 1-2 mm particles was useful to determine the most favorable conditions to treat the $0.250-1 \mathrm{~mm}$ soil fraction. The number of assays was also minimized from 29 to only 5 . Indeed, it was necessary to reduce the forces of the table motion and flowing film of water to enhance the treatment of the $0.250-1 \mathrm{~mm}$ soil fraction. The most favorable conditions were identified as follows: tilt of $11^{\circ}$, washing water flow of $5 \mathrm{~L} \mathrm{~min}^{-1}$, stroke length of $11 \mathrm{~mm}$, and stroke frequency of 352 strokes $\cdot \mathrm{min}^{-1}$. The results obtained under these conditions were less efficient than those obtained by dense media separation for the mass of the concentrate and $\mathrm{Pb}, \mathrm{Cu}$, and $\mathrm{Sn}$ removals, reflecting the limits of the shaking table as compared to dense media separation.

\section{Acknowledgements}

The authors thank Foncer Mine de Savoir, the Natural Sciences and Engineering Research Council of Canada (Project ID number: $R D C P J$ 418167-11) and Tecosol Inc. for their financial support. They also acknowledge the research assistant Myriam Chartier who provided precious help for the advancement of the project.

\section{Appendix A. Supplementary data}

Supplementary data related to this article can be found at https:// doi.org/10.1016/j.jenvman.2017.12.020.

\section{Uncited references}

Daniel and Cross, 2012, Design-Expert, 2017.

\section{References}

Abanades, S., Flamant, G., Gagnepain, B., Gauthier, D., 2002. Fate of heavy metals during municipal solid waste incineration. Waste Manag. Res. 20, 55-68.

Alloway, B., 2013. Heavy metals in soils. In: Trace Metals and Metalloids in Soils and Their Bioavailability, third ed. Springer, Netherlands, Netherlands, p. 614

Benschoten, J.E.V., Matsumoto, M.R., Young, W.H., 1997. Evaluation and analysis of soil washing for seven lead-contaminated soils. J. Environ. Eng. 123, 217-224.

Bisone, S., Mercier, G., Blais, J.-F., 2013. Decontamination of metals and polycyclic aromatic hydrocarbons from slag-polluted soil. Environ. Technol. 34, 2633-2648.

Burt, R., 1999. The role of gravity concentration in modern processing plants. Miner. Eng. 12, 1291-1300.

Burt, R., Wilson, M.A., Mays, M.D., Lee, C.W., 2003. Major and trace elements of selected pedons in the USA. J. Environ. Qual. 32, 2109-2121.

CEAEQ, 2010. Protocole de lixiviation pour les espèces inorganiques MA. $100-$ Lix.com.1.1.. Ministère du Développement durable, de l'Environnement et des Parcs du Québec, Quebec, Qc, Canada, 17.

Chandler, A., Eighmy, T., Hjelmar, O., Kosson, D., Sawell, S., Vehlow, J., Van der Sloot, H., Hartlén, J., 1997. Municipal Solid Waste Incinerator Residues, 1 ed. Elsevier, Netherlands, Netherlands, 973.

Chang, N.-B., Wang, H.P., Huang, W.L., Lin, K.S., 1999. The assessment of reuse potential for municipal solid waste and refuse-derived fuel incineration ashes. Resour. Conserv. Recycl. 25, 255-270.

Collett, R.S., Oduyemi, K., Lill, D.E., 1998. An investigation of environmental levels of cadmium and lead in airborne matter and surface soils within the locality of a municipal waste incinerator. Sci. Total Environ. 209, 157-167.

Dermont, G., Bergeron, M., Mercier, G., Richer-Laflèche, M., 2008. Soil washing for metal removal: a review of physical/chemical technologies and field applications J. Hazard Mater. 152, 1-31. 
Dong, J., Chi, Y., Tang, Y., Ni, M., Nzihou, A., Weiss-Hortala, E., Huang, Q., 2015. Partitioning of heavy metals in municipal solid waste pyrolysis, gasification, and incineration. Energy Fuels 29, 7516-7525.

Drzymała, J., Swatek, A., 2007. Mineral processing: Foundations of Theory and Practice of Minerallurgy. University of Technology, Wroclaw, Poland, 507.

Erikssonv, J., 2001. Concentrations of 61 Trace Elements in Sewage Sludge, Farmyard Manure, Mineral Fertiliser, Precipitation and in Oil and Crops. Department of Soil Sciences, Swedish University of Agricultural Sciences, Swedish, 69.

Falconer, A., 2003. Gravity separation: old technique/new methods. Phys. Separ. Sci. Eng. 12, 31-48.

Ferreira, S.L.C., Bruns, R.E., Ferreira, H.S., Matos, G.D., David, J.M., Brandão, G.C., da Silva, E.G.P., Portugal, L.A., dos Reis, P.S., Souza, A.S., dos Santos, W.N.L., 2007. Box-Behnken design: an alternative for the optimization of analytical methods. Anal. Chem. 597, 179-186.

Fitzpatrick, R.S., Ghorbani, Y., Hegarty, P.G.R., 2016. Quantitative Mineralogy for Improved Modelling of Shaking Tables, XXVIII International Mineral Processing Congress. Canadian Institute of Mining, Metallurgy and Petroleum, Quebec, Qc, Canada, 19.

FOREG, 2005. Forum of the European Geological Survey Directors. Geochemical Atlas Europe, Geological Survey of Finland, Espoo.

FRTR, 2016. Ex situ physical/chemical treatment (assuming excavation), USA. Accessible at the following adress: https://frtr.gov/matrix2/section4/4-19.html.

Gosselin, A., Blackburn, D., Bergeron, M., 1999. Assessment Protocol of the Applicability of Ore-processing Technology to Treat Contaminated Soils, Sediments and Sludges. Environment and Climate Change Canada, Canada, 142.

Govarthanan, M., Lee, G.-W., Park, J.-H., Kim, J.S., Lim, S.-S., Seo, S.-K., Cho, M., Myung, H., Kamala-Kannan, S., Oh, B.-T., 2014. Bioleaching characteristics, influencing factors of $\mathrm{Cu}$ solubilization and survival of Herbaspirillum sp. GW103 in $\mathrm{Cu}$ contaminated mine soil. Chemosphere 109, 42-48.

Guemiza, K., Coudert, L., Metahni, S., Mercier, G., Besner, S., Blais, J.-F., 2017. Treatment technologies used for the removal of As, $\mathrm{Cr}, \mathrm{Cu}, \mathrm{PCP}$ and/or PCDD/F from contaminated soil: a review. J. Hazard Mater. 333, 194-214.

Guo, X., Wei, Z., Wu, Q., Li, C., Qian, T., Zheng, W., 2016. Effect of soil washing with only chelators or combining with ferric chloride on soil heavy metal removal and phytoavailability: field experiments. Chemosphere 147, 412-419.

Harrison, R., Hester, R., 1994. Waste Incineration and the Environment. The royal society of chemistry, Thomas graham house, Science park, Cambridge, 158.

Horowitz, A.J., 1991. A Primer on Sediment-trace Element Chemistry, 2 ed. US Geological Survey, USA, 142.

Hutton, M., Wadge, A., Mllligan, P.J., 1988. Environmental levels of cadmium and lead in the vicinity of a major refuse incinerator. Atmos. Environ. 22, 411-416.

Iskandar, I., 2000. Environmental Restoration of Metals-contaminated Soils. Lewis Publishers, Boca Raton, London, New York, Washington, 320.

Jin, Y., Wu, Y., Cao, J., Wu, Y., 2014. Optimizing decolorization of Methylene Blue and Methyl Orange dye by pulsed discharged plasma in water using response surface methodology. J. Taiwan Inst. Chem. Eng. 45, 589-595.

Jobin, P., Coudert, L., Taillard, V., Blais, J.-F., Mercier, G., 2016a. Remediation of inorganic contaminants and polycyclic aromatic hydrocarbons from soils polluted by municipal solid waste incineration residues. Environ. Tech. 37, 1983-1995.

Jobin, P., Mercier, G., Blais, J.-F., 2016b. Magnetic and density characteristics of a heavily polluted soil with municipal solid waste incinerator residues: significance for remediation strategies. Int. J. Miner. Process. 149, 119-126.

Jobin, P., Mercier, G., Blais, J.-F., Taillard, V., 2015. Understanding the effect of attrition scrubbing on the efficiency of gravity separation of six inorganic contaminants. Water Air Soil Pollut. 226, 162.

Jordão, H., Sousa, A.J., Carvalho, M.T., 2016. Optimization of wet shaking table process using response surface methodology applied to the separation of copper and aluminum from the fine fraction of shredder ELVs. Waste Manag. 48, 366-373.

Kabata-Pendias, A., 2004. Soil-plant transfer of trace elements - an environmental issue. Geoderma 122, 143-149.

Kabata-Pendias, A., 2011. Trace Elements in Soils and Plants, fourth ed. CRC Press, Boca Raton, Fl, USA, 534

Kabata-Pendias, A., Dudka, S., 1991. Baseline data for cadmium and lead in soils and some cereals of Poland. Water Air Soil Pollut. 57, 723-731.

Khalid, S., Shahid, M., Niazi, N.K., Murtaza, B., Bibi, I., Dumat, C., 2017. A comparison of technologies for remediation of heavy metal contaminated soils. J. Geochem. Explor. 182, 247-268.
Lado, L.R., Hengl, T., Reuter, H.I., 2008. Heavy metals in European soils: a geostatistical analysis of the FOREGS Geochemical database. Geoderma 148, 189-199.

Laporte-Saumure, M., Martel, R., Mercier, G., 2010. Evaluation of physicochemical methods for treatment of $\mathrm{Cu}, \mathrm{Pb}, \mathrm{Sb}$, and $\mathrm{Zn}$ in Canadian small arm firing ranges backstop soils. Water Air Soil Pollut. 213, 171-189.

Marino, M.A., Brica, R.M., Neale, C.N., 1997. Heavy metal soil remediation: the effects of attrition scrubbing on a wet gravity concentration process. Environ. Prog.Prog. 16, 208-214.

Mehrotra, A.K., Singhal, R.K., 2000. In: Environmental Issues and Waste Management in Energy and Mineral Production, Illustrated. A.A. Balkema/Rotterdam/ Brookfield, Calgary, Alberta, Canada, p. 806.

Mercier, G., 2000. Disponibilité des métaux dans les sols et prévision du rendement d'enlèvement par des techniques minéralurgiques. $\mathrm{PhD}$ report Department of Geology and Geological Engineering, Laval University, Québec, Qc, Canada, 293.

Mercier, G., Duchesne, J., Blackburn, D., 2001. Prediction of metal removal efficiency from contaminated soils by physical methods. J. Environ. Eng. 127, 348-358.

Mocellin, J., Mercier, G., Morel, J.L., Blais, J., Simonnot, M.-O., 2015. Factors influencing the $\mathrm{Zn}$ and $\mathrm{Mn}$ extraction from pyrometallurgical sludge in the steel manufacturing industry. J. Environ. Manag. 158, 48-54.

Olawoyin, R., Oyewole, S.A., Grayson, R.L., 2012. Potential risk effect from elevated levels of soil heavy metals on human health in the Niger delta. Ecotoxicol. Environ. Saf. 85, 120-130.

Park, J.H., Lamb, D., Paneerselvam, P., Choppala, G., Bolan, N., Chung, J.-W., 2011 Role of organic amendments on enhanced bioremediation of heavy metal(loid) contaminated soils. J. Hazard Mater. 185, 549-574.

Peker, S., Helvaci, S., 2011. Solid-liquid Two Phase Flow. Elsevier Science, Netherlands, Netherlands, 534.

Prasad, M.N.V., Shih, K., 2016. Environmental Materials and Waste: Resource Recovery and Pollution Prevention, 1 ed. Academic press, Amsterdam, Boston, 750.

Santoleri, J., Theodore, L., Reynolds, J., 2000. Introduction to Hazardous Waste Incineration, second ed. Wiley, Canada, 656.

Stražišar, J., Sešelj, A., 1999. Attrition as a process of comminution and separation. Powder Technol. 105, 205-209.

Shacklette, H., Boerngen, J., 1984. Element Concentrations in Soils and Other Surficial Materials of the Coterminous United States. U.S. Department of the Interior, Geological Survey, United States.

Takeda, A., Kimura, K., Yamasaki, S., 2004. Analysis of 57 elements in Japanese soils, with special reference to soil group and agricultural use. Geoderma 119, 291-307.

Tanong, K., Coudert, L., Mercier, G., Blais, J.-F., 2016. Recovery of metals from a mixture of various spent batteries by a hydrometallurgical process. J. Environ. Manag. 181, 95-107.

Thornton, I., 2009. Metal Contamination of Soils in Urban Areas, Soils in the Urban Environment. Blackwell Publishing Ltd., 47-75.

Ucaroglu, S., Talinli, , 2012. Recovery and safer disposal of phosphate coating sludge by solidification/stabilization. J. Environ. Manag. 105, 131-137.

USEPA, 1995. Contaminants and Remedial Options at Selected Metal-contaminated Sites. Environmental Protection Agency, USA, 268.

Veetil, D.P., Mercier, G., Blais, J.-F., Chartier, M., Tran, L.H., Taillard, V., 2014. Remediation of contaminated dredged sediments using physical separation techniques. Soil Sediment Contam. 23, 932-953.

Wei, Y., Shimaoka, T., Saffarzadeh, A., Takahashi, F., 2011. Mineralogical characterization of municipal solid waste incineration bottom ash with an emphasis on heavy metal-bearing phases. J. Hazard Mater. 187, 534-543.

Weidemann, E., 2014. Waste Incineration Residues: Persistent Organic Pollutants in Flue Gas and Fly Ash from Waste Incineration. Ph.D. report University of Amsterdam, Amsterdam, Netherlands, 92.

Wills, B.A., 2011. Wills' Mineral Processing Technology: an Introduction to the Practical Aspects of Ore Treatment and Mineral Recovery. Butterworth, Amesterdam, Boston, Heidelberg, London, New York, Oxford, Paris, San Diego, San Francisco, Singapore, Sydney, Tokyo 7 ed., 456.

Yao, Z., Li, J., Xie, H., Yu, C., 2012. Review on remediation technologies of soil contaminated by heavy metals. Proced. Environ. Sci. 16, 722-729.

Youssef, M., Abd El-Rahman, K., Helal, N., El-Rabiei, M., Elsaidy, S., 2009. Optimization of shaking table and dry magnetic separation on recovery of Egyptian placer cassiterite using experimental design technique. J. Ore Dress. 11 (22), 9 